Article

\title{
Scenarios, Financial Viability and Pathways of Localized Hybrid Energy Generation Systems around the United Kingdom
}

\author{
Charles Newbold, Mohammad Akrami * (D) and Mahdieh Dibaj
}

check for

updates

Citation: Newbold, C.; Akrami, M.; Dibaj, M. Scenarios, Financial Viability and Pathways of Localized Hybrid Energy Generation Systems around the United Kingdom. Energies 2021, 14, 5602. https://doi.org/ $10.3390 /$ en14185602

Academic Editors: Beñat Landeta, German Arana and Athanasios I. Papadopoulos

Received: 11 July 2021

Accepted: 2 September 2021

Published: 7 September 2021

Publisher's Note: MDPI stays neutral with regard to jurisdictional claims in published maps and institutional affiliations.

Copyright: (c) 2021 by the authors. Licensee MDPI, Basel, Switzerland. This article is an open access article distributed under the terms and conditions of the Creative Commons Attribution (CC BY) license (https:// creativecommons.org/licenses/by/ $4.0 /)$.
Department of Engineering, University of Exeter, Exeter EX4 4QF, UK; can210@exeter.ac.uk (C.N.); m.dibaj3@exeter.ac.uk (M.D.)

* Correspondence: m.akrami@exeter.ac.uk

\begin{abstract}
Decarbonisation is becoming a central aim of countries around the globe, ensuring the effects of climate change do not increase exponentially in the coming years. Renewable energy generation is at the core of this decarbonisation process, enabling economies to divorce themselves from a reliance on oil and coal. Hybrid energy systems can utilise multiple generation methods to supply electrical demand best. This paper investigates the use of localised hybrid energy systems around the UK, comparing the financial viability of solar, wind and hydrokinetic generation methods both as a hybrid system and individually in different scenarios. The significance of having localised hybrid energy systems is that they address two large problems within renewable energy generation, that of storage issues and also generating the electricity far away from where it is actually used, requiring extensive infrastructure. The microgrid optimisation software HOMER was used to simulate each of the generation methods alongside the national grid, including lithium ion batteries and converters to create a comprehensive hybrid system. Net Present Cost, which is the current value of all the costs of installing and operating the system over the project lifetime, was considered as the metric. The analysis finds that for each modelled location, wind turbines in combination with lithium ion batteries and a converter is the system with the lowest Net Present Cost, with the exception of Bristol, which also uses hydrokinetic turbines within the system. The findings indicate the extensive wind resources available within the UK, along with identifying that certain locations around the country also have very high potential for tidal power generation.
\end{abstract}

Keywords: energy; decarbonisation; hybrid; wind; solar; hydrokinetic; United Kingdom

\section{Introduction}

Decarbonisation is now becoming a principal issue within the economic policies of developed countries, with the UK having set out a new plan to reduce its greenhouse gas emissions by $68 \%$ by the end of the decade compared to 1990 levels [1]. The importance of decarbonisation can be viewed on a global or domestic basis. From a global standpoint, climate change is having a dramatic effect on many planetary functions, such as fuelling extreme weather systems or causing food shortages through changing rain patterns [2-4]. The effect on animal life is also accelerating [5], with increased carbon dioxide concentrations and higher temperatures causing sea water to become more acidic [6]. Domestically in the UK, air pollution can increase the risk of many chronic and acute respiratory diseases and other cardiovascular health issues $[7,8]$. By reducing the emissions through decarbonisation methods, public health improves and the cost of health services reduces as well, with a current estimated cost of GBP 1.4-3.7 billion per year in London [9]. This study investigates the potential of wind, solar and hydrokinetic generation methods acting as a localised hybrid system for the supply of clean energy to specific cities in the UK. The hybrid system can include any of: the national grid, wind turbines, hydrokinetic turbines, solar panels, converters and lithium ion batteries for energy storage [10]. By identifying 
the most financially viable solutions, informed decisions can be made in terms of the location and makeup of the hybrid solutions. This offers a more systematic and achievable approach to the decarbonisation of cities, utilising the proximity of generation to reduce infrastructure costs and transmission losses.

Renewable energy is becoming a significant source of electricity production, with the global generation capacity increasing from 636.7 TWh in 2009 to 2805.5 TWh in 2019 [11]. This represents an annualised growth rate of $16 \%$ per annum for the decade of 2009 to 2019. Of the 2805.5 TWh of total generation, 1429.6 TWh was generated through wind, 724.1 TWh through solar and 651.8 TWh through other renewables such as geothermal and biomass [11]. While wind power makes up the majority of renewable capacity, the generation type experiencing the largest growth in 2019 was solar energy, with a growth rate of $24.3 \%$. Large scale solar projects such as Bhadla Park in India [12] and the Longyangxia Dam facility in China [13] have contributed significantly to the recent growth seen in solar generation capacity, with these projects totalling $2.2 \mathrm{GW}$ and $850 \mathrm{MW}$, respectively.

Currently, renewable energy generation occurs in very specific locations, often far away from where the electricity is actually used, resulting in grid losses and large infrastructure requirements for the transmission of that energy. Additionally, a large problem with renewables is that of over/under production depending on weather conditions and time of year. This paper aims to address both of these issues, by assessing the use of local energy hubs which factor both generation and storage methods into the cost of the system. Hybrid and localised systems are becoming more common solutions for energy generation [14-18], with greater research being undertaken into configurations and sizing methodologies for the systems [19]. For the specific locations of localised systems, one study investigated the effect of cities on wind patterns, finding that the complexity of airflows within cities makes it difficult to make accurate predictions, which could lead to installations of wind turbines at the incorrect location [20], something that must be addressed in subsequent hybrid system analyses.

The growth in renewables is likely to continue, with coordinated international efforts such as the Paris Agreement legally requiring countries to set ambitious targets every 5 years on climate action, known as Nationally Determined Contributions (NDCs). The object of the Paris agreement is to limit global warming to 1.5 degrees Celsius compared to pre-industrial levels [21] and to encourage a systematic approach to reaching net zero emissions by 2050. A report from the International Panel on Climate Change (IPCC) [22] details the potential impacts and risks associated with an increase in temperature greater than $1.5^{\circ} \mathrm{C}$, including extreme temperature fluctuations in certain locations and higher drought risks throughout arid areas. Such effects increase the necessity for countries to improve their carbon emissions, regardless of the relative ease of doing so. Countries such as Iceland and Scotland have considerable renewable resources that are being utilised in electricity generation. Iceland sits on the Mid-Atlantic ridge, a very active volcanic zone that helps to power geothermal plants. Additionally, seasonal meltwater runs from the mountains to the sea, creating natural channels for hydropower resources to be exploited. This natural landscape enables virtually $100 \%$ of electricity demand to be met with renewable sources [23]. Energy statistics for Scotland indicate that $97.4 \%$ of the country's gross electricity consumption was met through renewable sources [24], of which $71 \%$ comes from onshore and offshore wind generation. Moreover, there are also several cities around the world that are planning for being more sustainable through the decarbonisation and green strategies they have planned [25-27].

An emerging technology for which a large proportion of development is happening in Scotland is wave power. This encompasses a number of different methods of generation, with the main technologies being tidal barrages and horizontal axis hydrokinetic turbines. The hydrokinetic turbines work similarly to wind turbines, using the tidal stream to turn rotors that power a generator. The difference is that water is 832 times denser than air, and as such the energy density of flow is significantly higher. For a hydrokinetic turbine operating at $2-3 \mathrm{~m} / \mathrm{s}$, as much as four times more energy per square metre of rotor area 
can be harvested compared to a similarly power rated wind turbine [28]. Tidal barrage systems work very similarly to dammed hydropower installations in that the difference in height between two points can be utilised to drive a turbine. The tidal barrage spans a section of river or bay, with sluice gates that can be shut at any point to stop flow past the barrage. At low tide, the sluice gates open, allowing water to flow into the river until high tide, at which point the gates are closed to stop the water from returning as usual. The water is instead fed through turbines within the barrage to generate power as it is released. In each case, the predictability of ocean currents and tidal movement makes tidal energy an attractive energy source, enabling more straightforward grid power management due to lower variations in generation than wind turbines or solar. The drawback is that only certain locations are suitable for tidal generation to be economically competitive.

Another emerging technology is that of concentrated solar photovoltaics. This technology focusses solar irradiation onto a small area by means of a system of angled mirrors or lenses [29]. This creates a large amount of heat, which can either be used directly for heating, or as a means of driving a turbine to generate electricity. When a heat storage system is installed, the system is able to produce heat or electricity for a certain period of time after the sun has gone down. Similarly to tidal energy, the drawback is that the amount of solar irradiance required to reach a sufficiently high temperature can only be achieved in certain locations, such as North Africa, Australia and parts of the Western United States.

A large factor in making any renewable system an effective solution is the ability to store excess power for periods of time when it is not possible to generate power. The conventional approach is to use a lithium ion battery, with companies such as Tesla developing large scale battery systems with capacities of up to 3 MWh [30]. Promising new technologies aim to use gravitational potential to store energy, without the problems of battery ageing or temperature sensitivity experienced by the lithium ion. Gravitricity, as an example, is a startup that aims to harness this gravitational energy, initially using old mine shafts [31]. Excess power from renewables can be used to store energy by driving a winch that raises a weight of up to 12,000 tonnes up the mine shaft. When power is required, the weight can then be released to create electricity, with the speed of release offering either low power for sustained periods of time, or high peak power for a shorter duration. The Swiss company Energy Vault uses the same concept but instead with multiple concrete blocks being suspended from a six arm crane configuration [32]. The simplicity of design of these gravitational systems, along with the cheap materials used, has the potential for a significantly lower cost of energy storage in both capital expenditure and operating cost.

While for countries with greater renewable resources it is a good financial choice to invest in clean energy, countries that do not possess resources to the same extent have less incentive to invest in renewable energy. Lower energy costs may encourage businesses in these countries to invest in renewable energy since higher profits can be achieved without having to raise energy prices. Another study suggests that there is between $215 \mathrm{GW}$ and $250 \mathrm{GW}$ of potential tidal capacity in the British Isles [33], while an energy research unit in Oxford, UK estimated that there is an economically accessible wind energy potential of 675 GW at a levelised cost of GBP 110-120 per MWh [34]. This represents significant potential energy that can be harnessed through each method of generation, enabling the UK to move fully to renewable energy.

\section{Materials and Methods}

\subsection{Materials}

This study utilises HOMER Microgrid software [35] to identify and compare the most financially viable hybrid system in terms of the Net Present Cost of the solution. HOMER is a simulation model that simulates a viable solution for all possible combinations of the equipment chosen to be included within the system. Net Present Cost is the chosen metric by which to measure hybrid systems because, while a fully renewable system would be the 
ideal case scenario, the reality is that cost plays a pivotal role in deciding whether or not to pursue a project.

By simulating multiple locations around the UK, a comprehensive account of the available resources can be made. When modelled using the three different generation methods of solar, wind and hydro energy, it can be calculated whether certain locations in the country favour one generation type in particular. Three different sizes of wind turbine will be modelled so as to determine whether a larger or smaller size is the most effective within the hybrid system. Solar arrays of varying sizes will also be modelled so as to account for the economies of scale experienced within solar plants. When storage facilities are also included within the simulation, a fully hybrid system can be designed that will best deliver the electrical demand required. More state-of-the-art technology was considered; however, it was decided that it was not applicable for this specific study. For solar, state-of-the-art technology is concentrated solar power, which uses mirrors and lenses to focus light onto a receiver. The UK does not receive enough solar irradiation for this generation method to be plausible; therefore, it was not considered in the study. For storage methods, as mentioned in the Introduction section, gravitational storage methods offer very promising results; however, these are still in the developmental stage and as such were not considered within the simulation.

The data can also be used to determine the feasibility of the projects in terms of land area used and the environmental impact of manufacturing the specific system in different locations. While the simulation will present the lowest Net Present Cost hybrid system, data are additionally produced that show the lowest Net Present Cost of the individual generation methods. This data will also be analysed to gain an understanding of the proportion of individual generation methods supplying the electrical demand, and can be used to aid decision making on the feasibility of each system.

Modelled locations were chosen based on their current energy demand and any comparative advantage in resources that may be available. Specifically, only locations within the top $25 \%$ of electricity demand were considered, according to government statistics on sub-national electricity usage [36]. The comparative advantages in terms of resources were identified by analysing data from global wind and solar atlases [37,38], along with Admiralty tidal atlases for the UK waters [39]. By considering these factors, the chosen locations are shown in Table 1, with the annual and daily consumption figures along with the comparative advantage. For any tidal or wind turbines modelled, the specific location is within 20 miles of the city, given that the tidal resource is rarely in the city itself, and the wind resource can be complex. Scotland has not been included in the choice of locations because the renewable resource already produces $31.8 \mathrm{TWh}$ per annum, the equivalent of $97.4 \%$ of the gross electricity consumption of the country [24]. The exception to these location selection criteria is Exeter. Exeter has been simulated as an example of a smaller electrical load demand.

Table 1. Modelling locations information.

\begin{tabular}{cccc}
\hline Location & Comparative Advantage & Annual Energy Demand (GWh) & Daily Energy Demand (kWh) \\
\hline Bournemouth & Solar & 1473 & $4,035,616$ \\
Brighton & Solar & 928 & $2,542,466$ \\
Bristol & Hydro & 1769 & $4,846,575$ \\
Exeter & Solar & 544 & $1,517,808$ \\
Leicester & Wind & 1310 & $3,589,041$ \\
Manchester & Wind & 2544 & $6,969,863$ \\
Newcastle & Wind & 1187 & $3,252,055$ \\
Plymouth & Solar & 882 & $2,416,438$ \\
Portsmouth & Hydro & 880 & $2,410,959$ \\
Swansea & Hydro & 888 & $2,432,877$ \\
\hline
\end{tabular}

The solar and wind atlas data are shown visually in Figures 1 and 2, with the scale for the intensity of each resource shown at the top right of the figure. It can be seen that 
Bournemouth, Brighton and Plymouth are in close proximity to higher solar irradiance, while Manchester, Newcastle and Leicester are close to extensive wind resources.

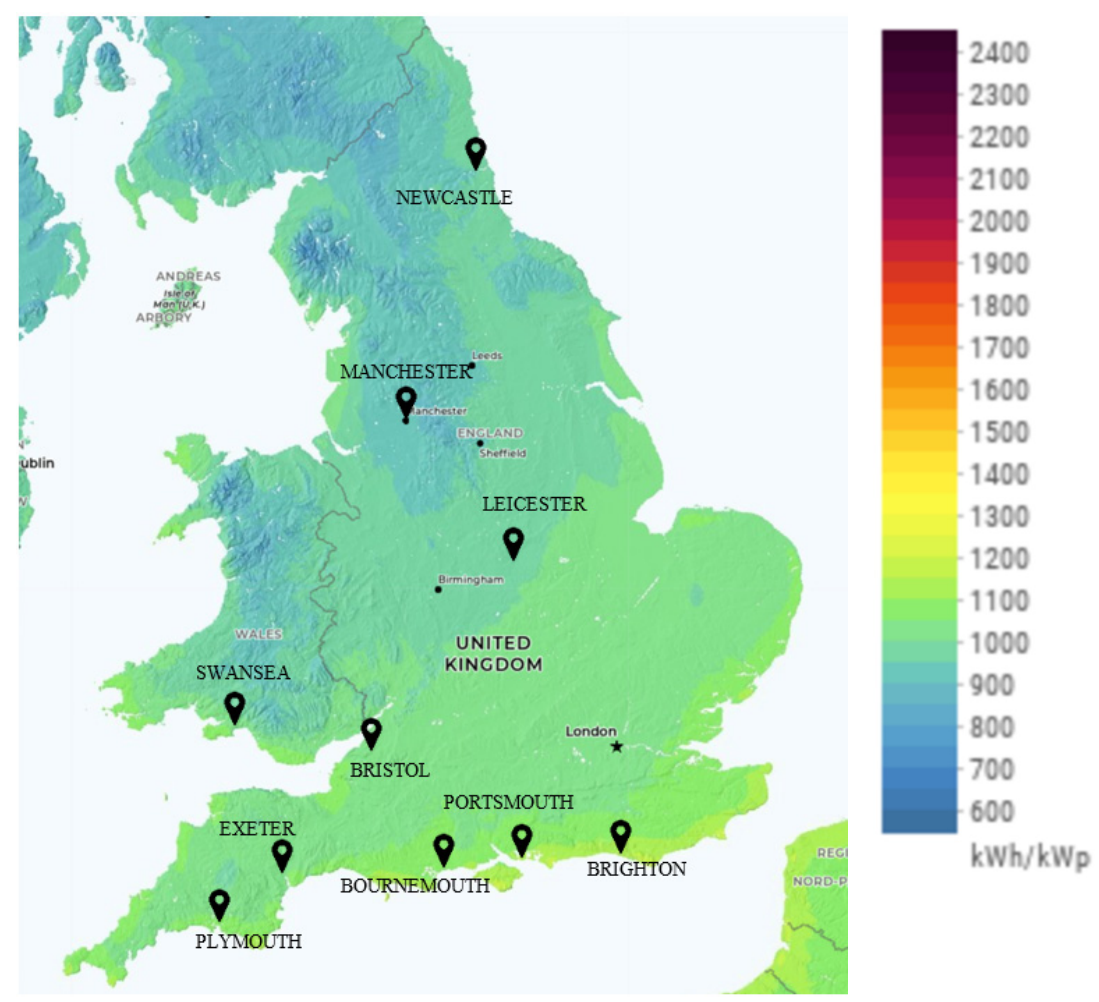

Figure 1. Solar atlas data of chosen locations [38].

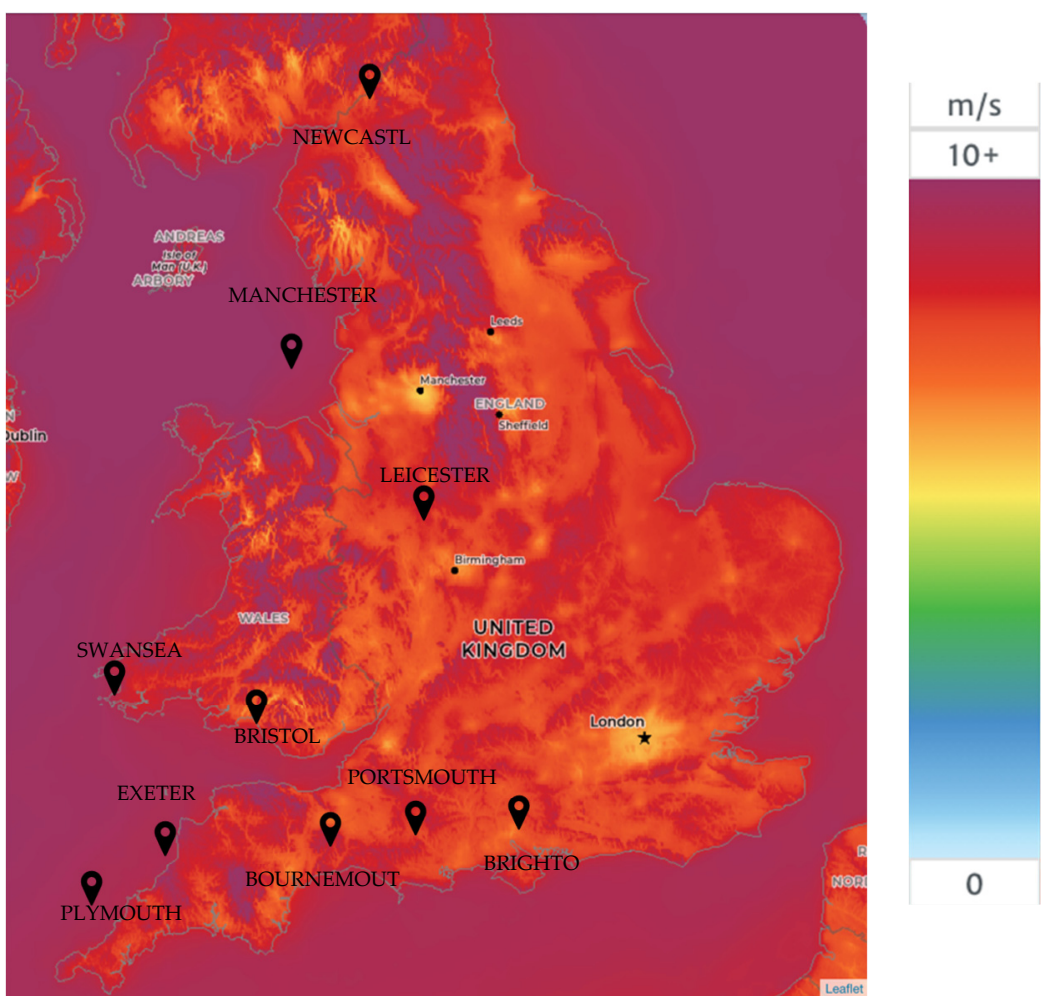

Figure 2. Wind atlas data of chosen locations [38].

Figure 3 provides an example of how the Admiralty tidal atlases show tidal stream data. The location shown is for Bristol, with the specific point at which turbines are being 
modelled highlighted within the red boxes. A different page is given for each of the hourly time steps from $6 \mathrm{~h}$ before to $6 \mathrm{~h}$ after high water at Dover. The specific pages shown are at 5 and $3 \mathrm{~h}$ after high water at Dover. These are being shown to give an indication of the fluctuation in power output which will be experienced by the turbine throughout the day due to the changing tidal speeds. The two values at each point represent neap and spring tide rates, a factor which is considered when calculating the average tidal resource for each location. The hourly data can be manipulated to achieve a useful format which can be input into HOMER.

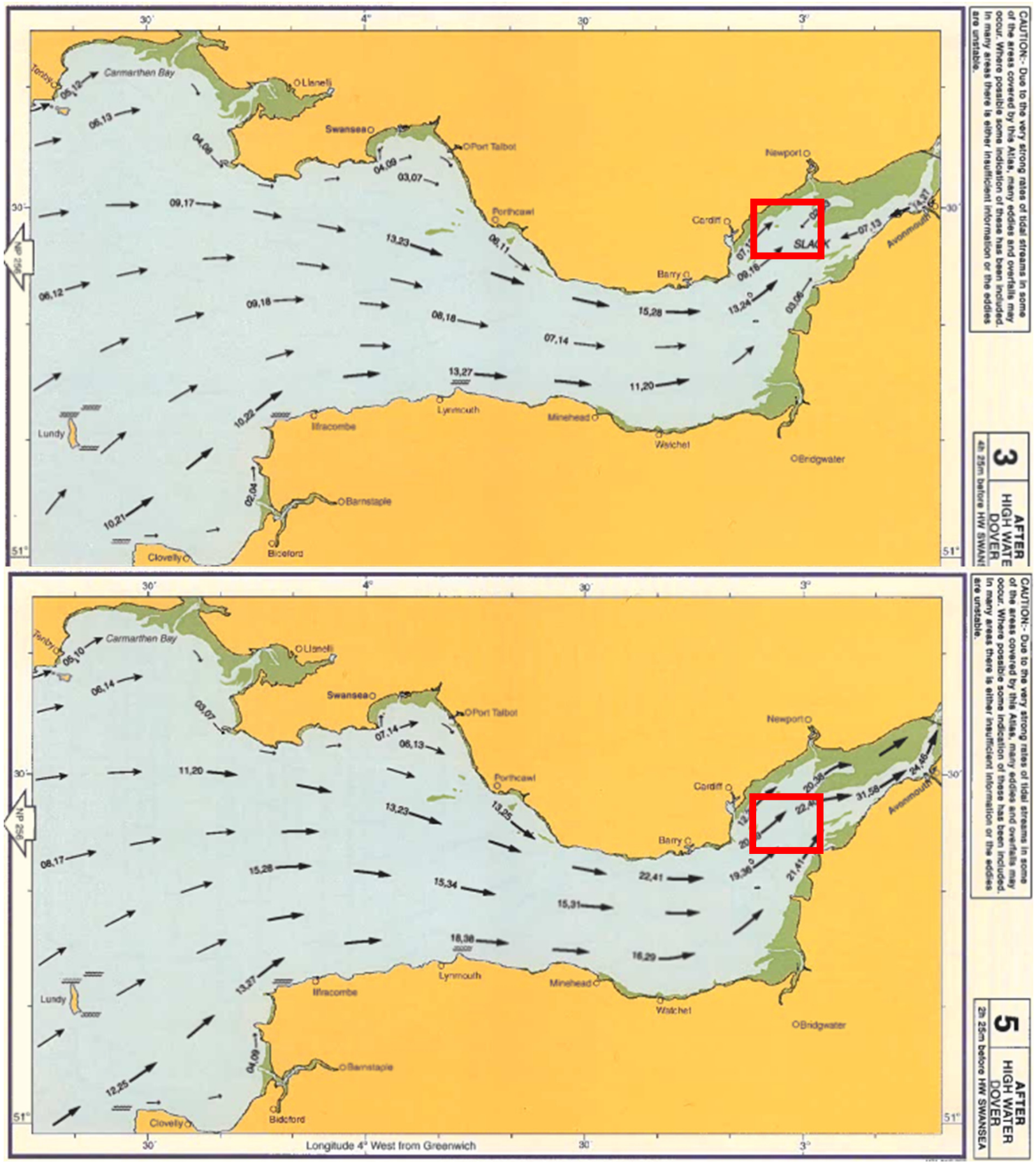

Figure 3. Tidal atlas data for Bristol [39]. 


\subsection{Theory and Calculation}

The HOMER software was chosen because of the ability of the software to consider optimal microgrid design. The software is capable of considering systems of all sizes, even small villages running off a diesel generator. However, the software has been programmed using the UK national grid system as the base delivery of power for this simulation. Renewable generation sources can be added, using resource data to calculate the contribution to electrical demand that can be supplied, and the associated costs of using this type of generation as opposed to the grid. The simulation can be programmed to operate a microgrid system for an entire year in time steps of one minute to one hour. For this study, time steps of one hour were chosen, since the purpose is to gain a high-level understanding of the resources available and most efficient system at each location, rather than predict the specific production of each generation method each minute. The optimisation software within HOMER uses an algorithm to determine the system that best serves the electrical demand, based on the desired output. The Optimizer is discussed further within the Experimental section. HOMER optimises the system based on the architecture, or amount of each piece of hardware, with the lowest Net Present Cost. Based on this architecture, the Renewable Fraction of the system is shown, which is the proportion of the electricity demand supplied through renewable sources. HOMER uses the resources available along with the production profile of the specific pieces of hardware to calculate this fraction.

The Net Present Cost is the present value of the installation and operational costs of the entire system, not accounting for any revenues generated by the sale of electricity from the system over its entire lifetime. The discount rate is the interest rate used to determine the present value of future cash flows in Discounted Cash Flow Analysis. This may also be applied to the system, in which case HOMER calculates the discounted costs by multiplying the nominal costs by the discount factor.

The discount factor is calculated using the real discount rate and number of years the discount is applied for, shown in Equation (1) [35];

$$
\text { Discount factor }=\frac{1}{(1+i)^{N}}
$$

where:

$i=$ Real discount rate $(\%)$

$N=$ Number of years

A key metric for evaluating the system is the levelised cost of energy. This is defined as the average cost per kWh of useful electricity generated by the system. This is a particularly useful metric because it enables the comparison between the effectiveness of differently sized systems. For systems that incorporate a generator or other forms of combustion to generate power, the cost of energy is calculated using Equation (2) [35];

$$
\text { COE }=\frac{C_{\text {ann,tot }}-c_{\text {boiler }} H_{\text {served }}}{E_{\text {served }}}
$$

where:

$C_{a n n, t o t}=$ Total annualised cost $(\mathrm{GBP} £ /$ year $)$

$C_{\text {boiler }}=$ Boiler marginal cost $(\mathrm{GBP} £ / \mathrm{kWh})$

$H_{\text {served }}=$ Total thermal load served $(\mathrm{kWh} /$ year $)$

$E_{\text {served }}=$ Total electrical load served $(\mathrm{kWh} /$ year $)$

None of the PV, solar or hydrokinetic systems used requires a thermal load to be met, and therefore the cost of energy can be found using Equation (3) [35];

$$
\mathrm{COE}=\frac{C_{\text {ann,tot }}}{E_{\text {served }}}
$$

A number of further outputs can be useful in analysing any given system, enabling the consideration of factors other than the present cost of the system or the cost of energy. 
The initial capital shows the total capital required to install all components at the beginning of the project, while the operating cost is the annualised value of all costs and revenues other than the initial capital outlay. The operating cost is calculated using Equation (4) [35];

$$
C_{\text {operating }}=C_{\text {ann,tot }}-C_{a n n, c a p}
$$

where:

$C_{\text {ann }, \text { tot }}=$ Total annualised cost $(\mathrm{GBP} £ /$ year $)$

$C_{a n n, \text { cap }}=$ Total annualised capital cost (GBP $£ /$ year)

The revenues generated can be accounted for using the discounted payback time, which is the number of years it would take to recover the difference in investment costs between the simulated and base systems. This can be determined by the point at which the discounted cash flow line crosses the cash flow line of the base system. This is a very useful indicator, especially with regard to the initial capital and operating cost. Since the initial capital required to implement systems is often very high, a low projected payback time can give investors more confidence to invest the capital and sustain the operating cost in the knowledge that returns will be made quickly. HOMER shows the results of the simulations ranked by the lowest Net Present Cost; however, the architecture of the system, cost of energy, initial capital and renewable fraction can all be viewed easily in the results space, enabling factors other than present cost to be taken into account when choosing a system if required.

The data referred to above can be manipulated in order to produce outputs that analyse the system but are independent of the size of the value itself or the system. This enables a better comparison between locations, along with highlighting key information within each system individually. The percentage contribution of each component to the total electricity generation is one metric that is independent of size, and can be calculated using Equation (5) [35];

$$
\text { Percentage of generation }=\frac{\text { Component annual generation }}{\text { Total annual generation }}
$$

The percentage generation can be used to calculate the total emissions saved by the system, and as such the cost per tonne of $\mathrm{CO}_{2}$ removed by the system. The individual component contributions to total electricity production ratio is an important statistic because each generation method and storage component produces different emissions per $\mathrm{kWh}$. The values used to calculate the individual emissions are shown in Table 2, with the grid emissions value from government conversion factors included so as to calculate the emissions saved.

Table 2. Emissions of production associated with components.

\begin{tabular}{ccc}
\hline Location & $\begin{array}{c}\text { Emissions } \\
\left(\mathbf{k W C O} \mathbf{O}_{\mathbf{2}} \mathbf{e} \text { per } \mathbf{k W h}\right)\end{array}$ & Reference \\
\hline Grid & 0.2556 & {$[35]$} \\
Wind turbine & 0.025 & {$[36]$} \\
Hydro turbine & 0.015 & {$[36]$} \\
Solar panels & 0.058 & {$[37]$} \\
Lithium ions & 0.061 & {$[38]$} \\
\hline
\end{tabular}

The specific equation used for determining the cost per tonne of $\mathrm{CO}_{2}$ saved is shown in Equation (6) [35];

$$
\text { Cost per tonne }=\frac{\text { Base system emissions }- \text { Hybrid system emissions }}{\text { Net Present Cost }}
$$

The solar and wind data for each location can be downloaded to HOMER from NASA Prediction of Worldwide Energy Resources databases [40]. Solar data are downloaded 
as GHI data (Global Horizontal Irradiance). This is the total solar radiation incident on a horizontal surface, and is the sum of the DNI (Direct Normal Irradiance) and ground reflected radiation. Table 3 gives a list of average radiation received and the clearness index of each location, while Figure 4 shows a graphical plot of this data for Brighton and Newcastle, the highest and lowest solar irradiance values, respectively.

Table 3. Solar irradiance and clearness index values.

\begin{tabular}{ccc}
\hline Location & $\begin{array}{c}\text { Average Solar Irradiance } \\
\left(\mathbf{k W h} / \mathbf{m}^{\mathbf{2}} / \mathbf{d a y}\right)\end{array}$ & Average Clearness Index \\
\hline Bournemouth & 3.15 & 0.446 \\
Brighton & 3.15 & 0.448 \\
Bristol & 2.64 & 0.382 \\
Exeter & 2.96 & 0.419 \\
Leicester & 2.64 & 0.396 \\
Manchester & 2.7 & 0.402 \\
Newcastle & 2.61 & 0.409 \\
Plymouth & 3.11 & 0.433 \\
Portsmouth & 3.15 & 0.448 \\
Swansea & 2.64 & 0.383 \\
\hline
\end{tabular}
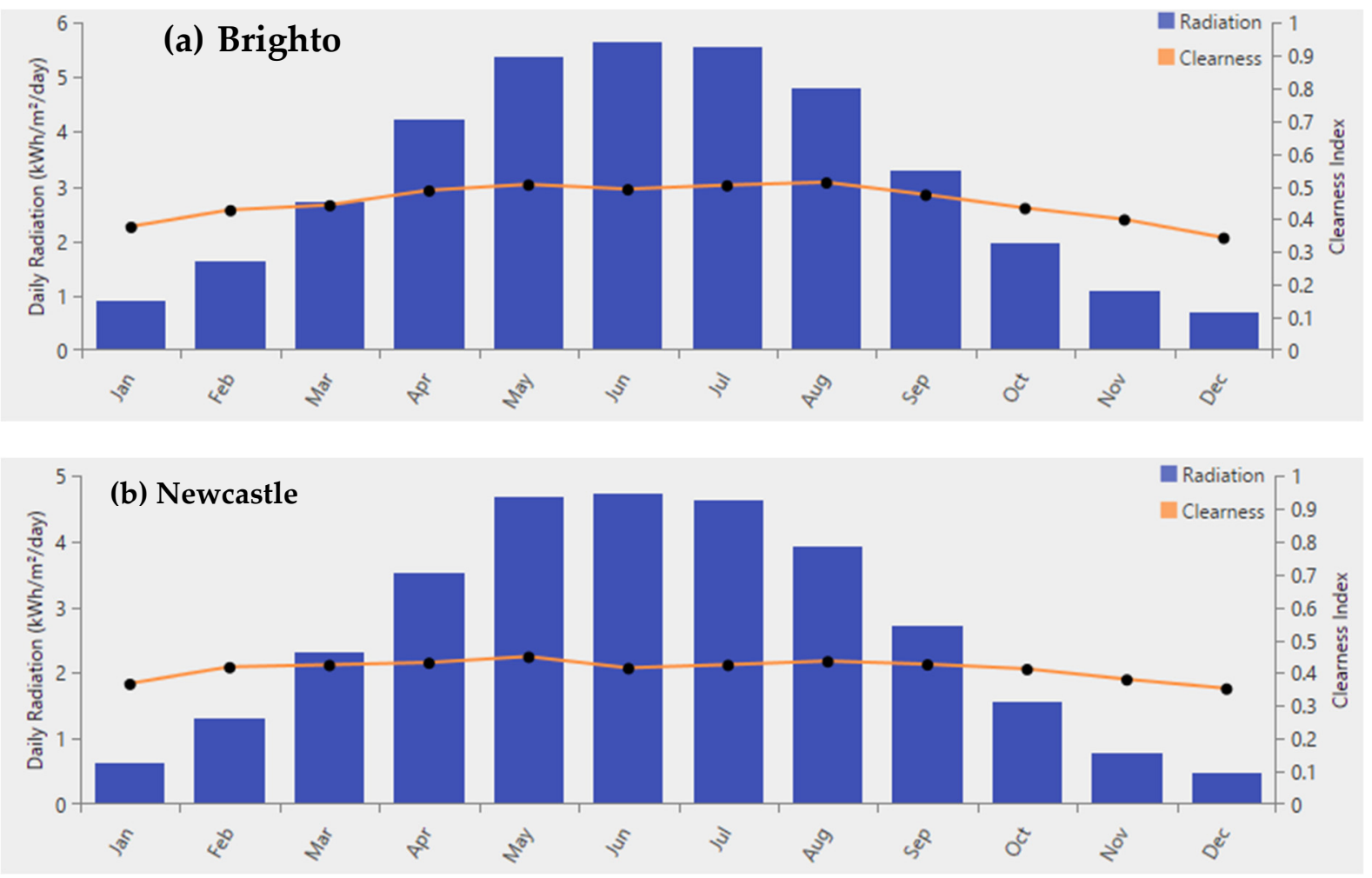

Figure 4. Monthly solar GHI resource for (a) Brighton and (b) Newcastle.

Monthly wind resource is calculated using specific parameters that enable a more realistic model to be made of the available resource. These parameters are:

- Weibull K value-Reflects the breadth of a distribution of wind speeds. This can be used to account for gusty locations that have fluctuating wind speeds

- Diurnal pattern strength-Reflects how strongly the wind speed tends to depend on the time of day

- Hour of peak windspeed-The hour of day that, on average, tends to be the windiest

- $1 \mathrm{~h}$ autocorrelation factor-Reflects how strongly the wind speed in one time step depends on the wind speeds in previous time steps 
Table 4 shows the wind resource at each location, while Figure 5 shows the monthly breakdown for Newcastle, which has a high average wind speed of $8.14 \mathrm{~m} / \mathrm{s}$ and peak average of $9.91 \mathrm{~m} / \mathrm{s}$ in January, despite having the lowest solar irradiance value of the study. It can be seen that the wind speed is higher from October through to February, correlating with the months of highest demand.

Table 4. Wind resource at each location.

\begin{tabular}{cc}
\hline Location & Average Wind Speed $(\mathrm{m} / \mathrm{s})$ \\
\hline Bournemouth & 7.85 \\
Brighton & 7.82 \\
Bristol & 7.29 \\
Exeter & 7.74 \\
Leicester & 8.06 \\
Manchester & 8.24 \\
Newcastle & 8.14 \\
Plymouth & 7.68 \\
Portsmouth & 7.84 \\
Swansea & 7.54 \\
\hline
\end{tabular}

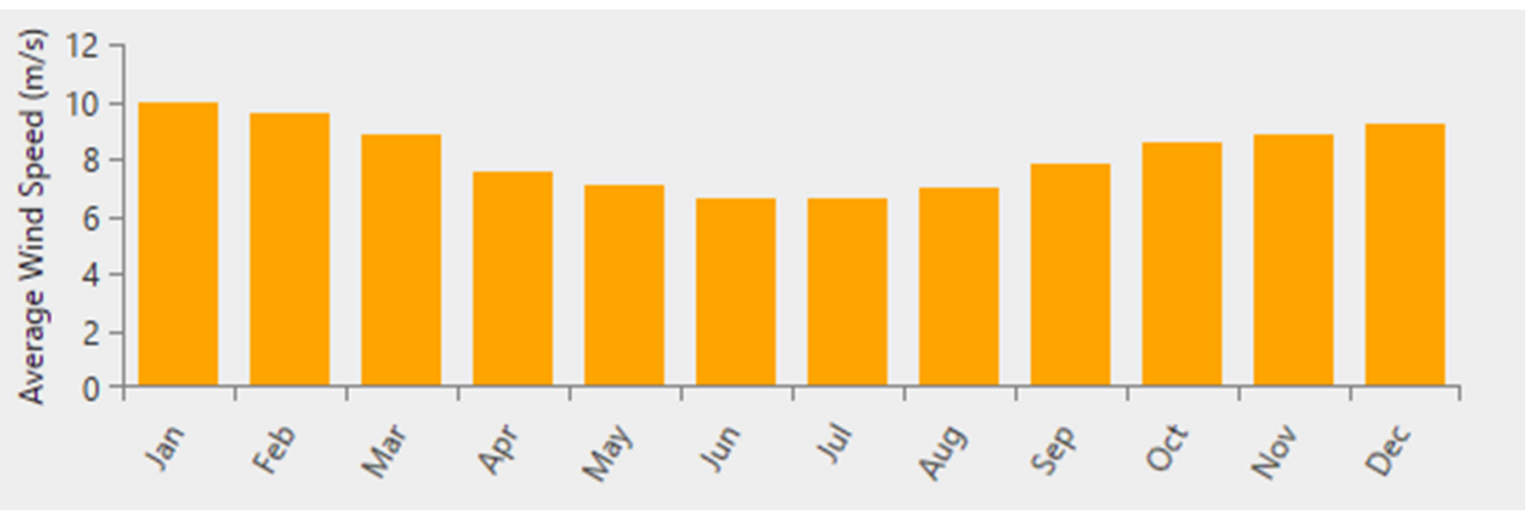

Figure 5. Monthly wind resource for Newcastle.

The tidal average is more difficult to determine. The Admiralty tidal atlases provide tidal stream data at different times of day, namely within $6 \mathrm{~h}$ before and after the high-water time. At each time step, two separate values are included. These represent the spring and neap tide flow rates, given in knots. So as to ensure the actual tidal resource is modelled rather than a biased value of either the spring or neap tidal rates, an equal split of neap and spring rates has been input into HOMER as the hydrokinetic resource. This is shown in Figure 6, which shows the tidal resource at Bristol, the highest within the study.

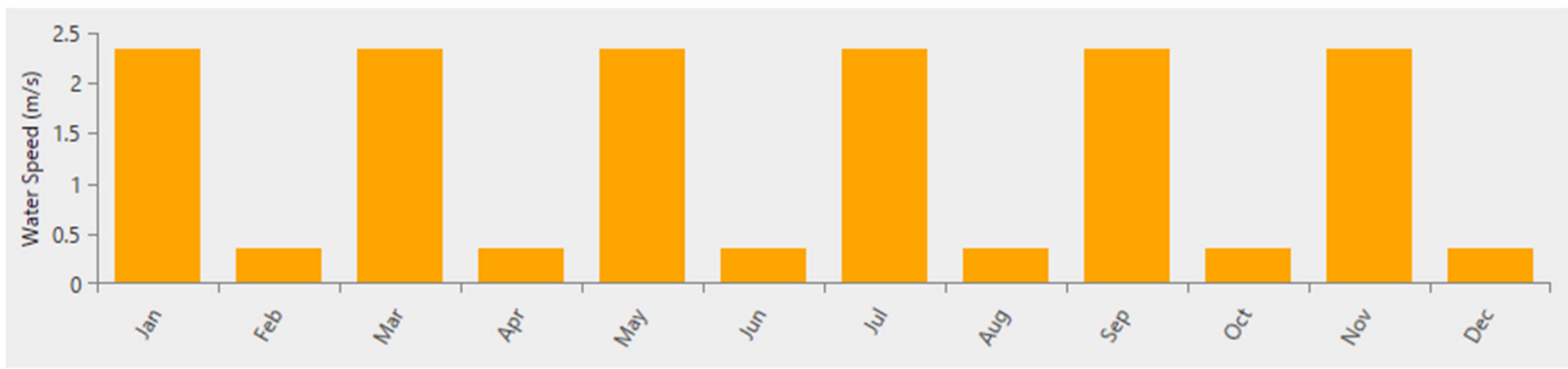

Figure 6. Hydrokinetic resource of Bristol. 
However, this flow rate cannot be taken as a simple average flow rate value for the spring and neap values. This is because power is produced from hydrokinetic turbines in a cubic relationship relative to the velocity, as shown in Equation (7) [31];

$$
P(t)=\frac{1}{2} \rho A v(t)^{3}
$$

To find the average speed, the power generation at each time step was calculated, using a constant value for the area. These values were then summed and the average velocity found by manipulation of the Equation (7) to give Equation (8) [35];

$$
v(t)=\sqrt[3]{\frac{2 P(t)}{\rho A}}
$$

However, the cut in speed in the turbine of $0.8 \mathrm{~m} / \mathrm{s}$ must be taken into account. Since the turbine will not be producing any power under speeds of $0.8 \mathrm{~m} / \mathrm{s}$, any lower tidal speed values are said to produce $0 \mathrm{~W}$ of power, thus adjusting the average for realistic production from the turbine. This calculation process and any adjustments are shown in Table 5, which shows the tidal data for Bristol. The remaining hourly data and individual average speeds are shown in Appendix A.

\begin{tabular}{|c|c|c|c|c|c|c|}
\hline \multirow{2}{*}{ BRISTOL } & \multicolumn{2}{|c|}{ Speed (knots) } & \multicolumn{2}{|c|}{ Speed (m/s) } & \multicolumn{2}{|c|}{ Power (J) } \\
\hline & Neaps & Springs & Neaps & Springs & Springs & Neaps \\
\hline $6 \mathrm{~B}$ & 23 & 43 & 1.183 & 2.212 & 847.312 & 5536.883 \\
\hline $5 B$ & 16 & 29 & 0.823 & 1.492 & 285.246 & 1698.455 \\
\hline $4 \mathrm{~B}$ & 9 & 16 & 0.463 & 0.823 & 0 & 285.246 \\
\hline $3 B$ & 6 & 11 & 0.309 & 0.566 & 0 & 0 \\
\hline $2 B$ & 16 & 30 & 0.823 & 1.543 & 285.246 & 1880.285 \\
\hline $1 \mathrm{~B}$ & 20 & 38 & 1.029 & 1.955 & 557.122 & 3821.297 \\
\hline HW & 20 & 37 & 1.029 & 1.903 & 557.122 & 3527.485 \\
\hline $1 \mathrm{~A}$ & 20 & 37 & 1.029 & 1.903 & 557.122 & 3527.485 \\
\hline $2 \mathrm{~A}$ & 17 & 32 & 0.875 & 1.646 & 342.142 & 2281.970 \\
\hline $3 \mathrm{~A}$ & 7 & 13 & 0.360 & 0.669 & 0 & 0 \\
\hline $4 \mathrm{~A}$ & 18 & 34 & 0.926 & 1.749 & 406.142 & 2737.138 \\
\hline $5 \mathrm{~A}$ & 31 & 58 & 1.595 & 2.984 & 2074.651 & $13,587.637$ \\
\hline \multirow[t]{2}{*}{$6 \mathrm{~A}$} & 26 & 48 & 1.338 & 2.469 & 1223.996 & 7701.648 \\
\hline & & & & $\begin{array}{c}\text { TOTAL } \\
\text { AVERAGE }\end{array}$ & \multicolumn{2}{|c|}{2066} \\
\hline & Area & Combir & average & eed $(\mathrm{m} / \mathrm{s})$ & \multicolumn{2}{|c|}{ Individual average speed $(\mathrm{m} / \mathrm{s})$} \\
\hline 1023 & 1 & & 1.347 & & $\begin{array}{c}\text { Neaps } \\
0.358\end{array}$ & $\begin{array}{l}\text { Springs } \\
2.335\end{array}$ \\
\hline
\end{tabular}

Table 5. Calculation process for Bristol tidal average.

HOMER was programmed to optimise the system based on different energy demand profiles, namely residential, community, commercial and industrial. For this model, the community demand profile has been used, since this is the demand that is experienced within cities. A peak month of demand of January is also chosen, since this models the higher winter demand experienced in the UK. The demand profile can be scaled to fit any electrical demand, based on the daily average consumption of the location. These are the values shown in Table 1 within the Methodology section. A visual representation of both the daily and monthly electrical loads can be seen in Figures 7 and 8. Figure 7 shows a data map of Portsmouth, where it can be seen that there are small peaks in demand between 08:00 and 11:00, with the highest demand being experienced between the hours of 17:00 and 23:00. Figure 8 shows the corresponding monthly demand profile as a box plot so as to show the real fluctuations that will be experienced day to day, instead of simply an average value. The demand follows a clear trend, with winter months demanding greater energy and summer months having lower demand. However, the most visible difference 
is the spread in values for summer and winter, with the winter maximum values being considerably higher, with a peak demand of $358,420.72 \mathrm{~kW}$. The electricity price is taken as GBP 0.195 per $\mathrm{kWh}$, as this was the average cost of electricity in the UK between January and June 2020 according to Ofgem statistics [41].

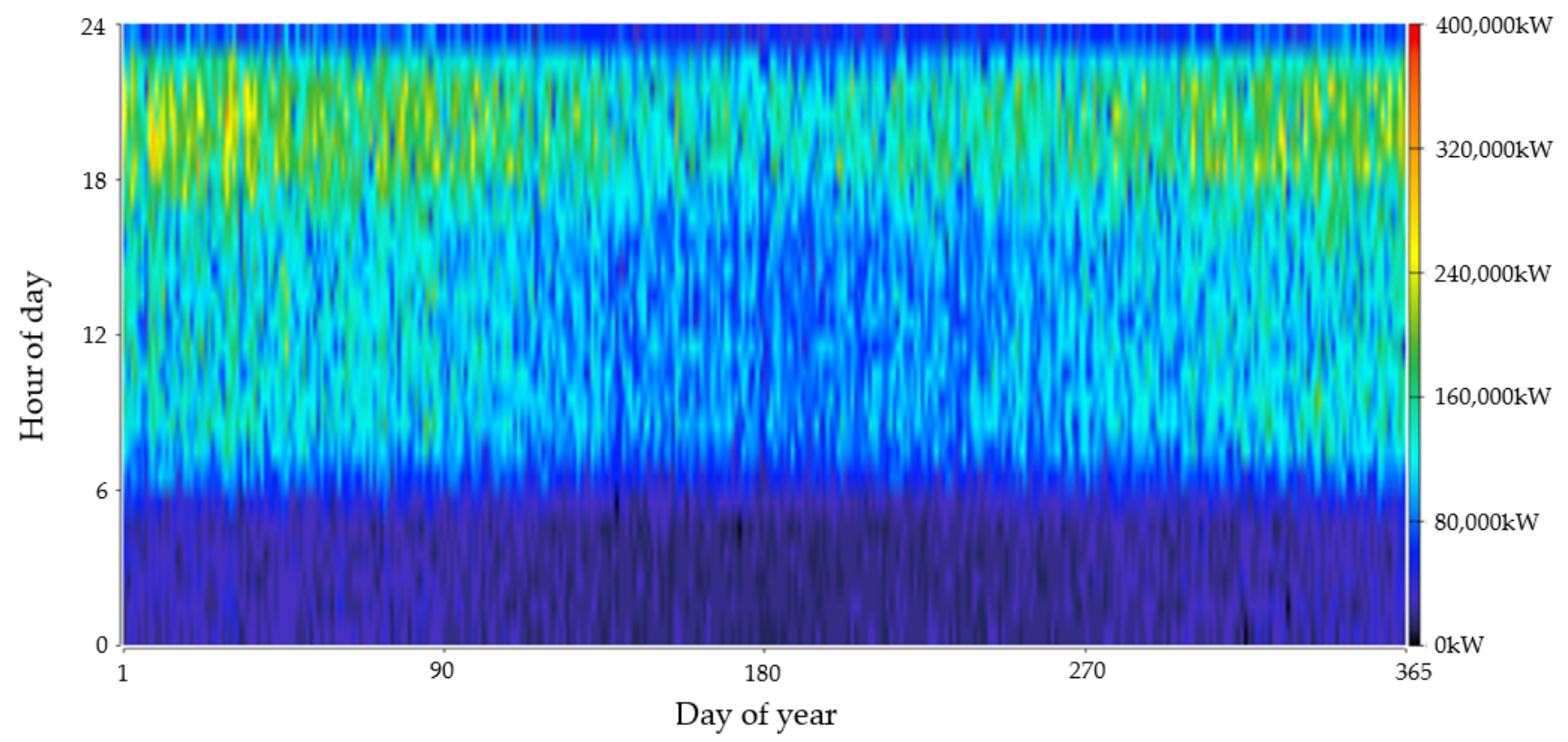

Figure 7. Data map of hourly electricity consumption for Portsmouth.

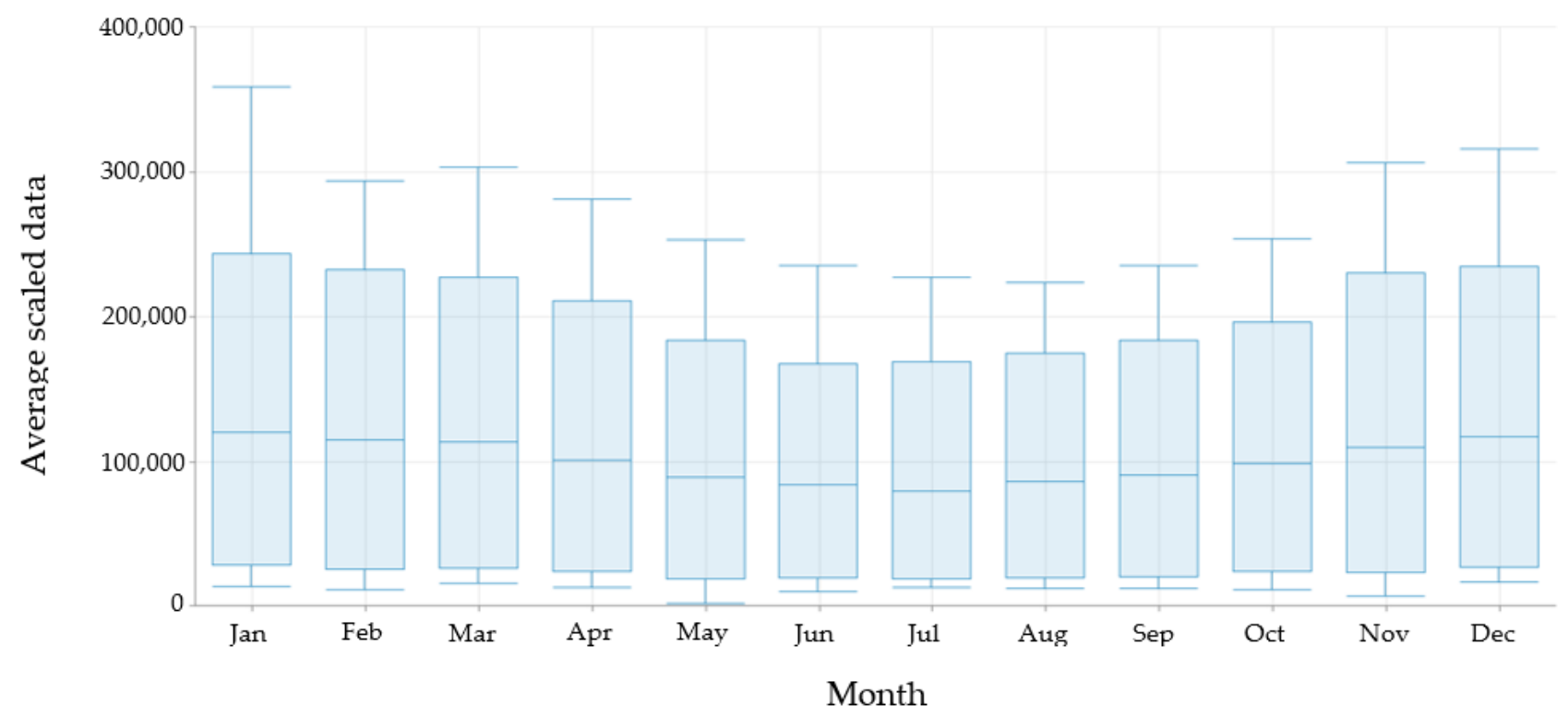

Figure 8. Monthly average electricity consumption of Portsmouth.

Further relevant parameters for the study are shown in Table 6. HOMER calculates the real discount rate as discussed in the Methodology section. The chosen inflation rate of $2 \%$ is the target rate for the Bank of England. While the current rate during the Coronavirus pandemic is $0.7 \%$, this is not representative of more normal circumstances. The discount rate of $8 \%$ and the project lifespan of 25 years are standard values. 
Table 6. Other input parameters.

\begin{tabular}{cc}
\hline Location & Value \\
\hline Currency & GBP \\
Inflation rate & $2 \%$ \\
Discount rate & $8 \%$ \\
Real discount rate & $5.88 \%$ \\
Project lifespan & 25 years \\
\hline
\end{tabular}

The generation hardware modelled are practically sized pieces of equipment at real prices, ensuring the simulations produce a realistic output. For the wind turbines, three different sizes have been simulated. These are $900 \mathrm{~kW}, 2.5 \mathrm{MW}$ and $4 \mathrm{MW}$, based on the EWT DW 61, GE 2.5-120 and Enercon E126 EP3 turbines, respectively. The solar arrays modelled are $1 \mathrm{~kW}, 12 \mathrm{~kW}, 100 \mathrm{~kW}$ and $1000 \mathrm{~kW}$, since these are common sizes for household or industrial arrays. Since hydrokinetic turbines are a relatively new technology, only one turbine has been modelled, as there are not significant data available on other models. The modelled hydrokinetic turbine is an AR1500 made by Simec Atlantis. The specific costs of each component are shown in Table 7, with the annual operational cost and lifetime also included.

Table 7. Component sizes and costs.

\begin{tabular}{|c|c|c|c|c|}
\hline Component & Initial Cost $(\mathrm{GBP}, £)$ & $\begin{array}{c}\text { Operational Cost } \\
(G B P, £)\end{array}$ & Lifetime & Reference \\
\hline $900 \mathrm{~kW}$ wind turbine & $1,000,000$ & 15,000 & 20 & [41] \\
\hline 2.5 MW wind turbine & $2,000,000$ & 25,000 & 20 & [42] \\
\hline $4 \mathrm{MW}$ wind turbine & $2,500,000$ & 30,000 & 20 & [41] \\
\hline $1 \mathrm{~kW}$ solar array & 1500 & 10 & 25 & [43] \\
\hline $12 \mathrm{~kW}$ solar array & 13,000 & 150 & 25 & [43] \\
\hline $100 \mathrm{~kW}$ solar array & 95,000 & 1250 & 25 & [44] \\
\hline 1000 kW solar array & 850,000 & 5000 & 25 & [45] \\
\hline 1.5 MW hydro turbine & $2,170,000$ & 30,000 & 25 & [46] \\
\hline Lithium ion battery $(\mathrm{kWh})$ & 137 & 2 & Degradation of $30 \%$ & {$[47]$} \\
\hline Converter & 300 & 0 & 15 & [48] \\
\hline
\end{tabular}

Any conversions between Dollars and Pounds are taken at 1 USD $=0.7229$ GBP [42]. Any conversions between Euros and Pounds are taken at $1 \mathrm{EUR}=0.8353 \mathrm{GBP}$ [43].

A lithium ion battery is also included within the model, to allow the system to check whether installing battery storage is a financially efficient solution. The wind and hydrokinetic turbines both produce power as AC current, while the solar panels and lithium ion battery both produce power as DC current. To allow the turbines to store any excess energy they may produce, along with allowing the lithium ion battery and solar panels to provide power to the grid, a converter must also be included within the system. The efficiency of the converter is modelled as a standard value of $95 \%$. Information on each component is included within Table 7.

The makeup of the system can be easily visualised with a schematic diagram. Figure 9 shows the schematic used for each location, where the differentiation between the AC and DC systems can be clearly identified, along with the peak electrical load which will be experienced. The peak load of 361,679.12 kW shown in Figure 9 is that for Swansea, whilst the remaining peak loads are shown in Table 8. 


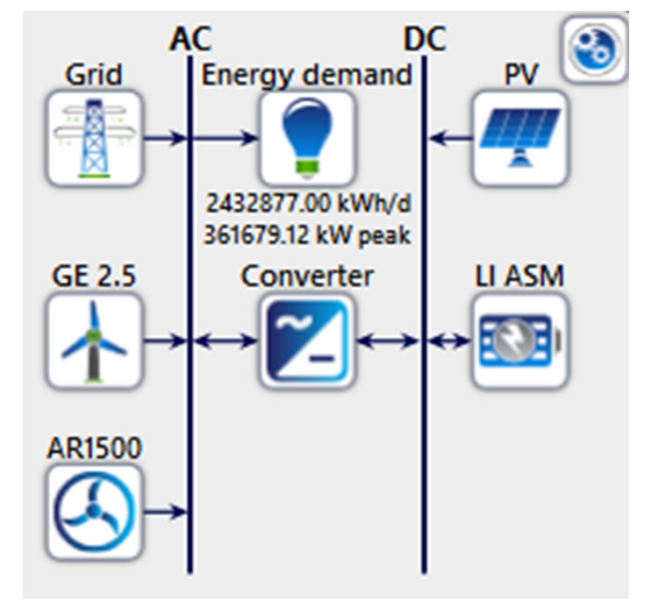

Figure 9. Schematic diagram for Swansea.

Table 8. Peak electrical load at each location.

\begin{tabular}{cc}
\hline Location & $\begin{array}{c}\text { Peak Electrical Load } \\
\text { (kW Peak) }\end{array}$ \\
\hline Bournemouth & $599,947.33$ \\
Brighton & $377,970.97$ \\
Bristol & $720,507.03$ \\
Exeter & $225,642.10$ \\
Leicester & $533,558.09$ \\
Manchester & $1,036,161.68$ \\
Newcastle & $483,460.69$ \\
Plymouth & $359,235.25$ \\
Portsmouth & $358,420.72$ \\
Swansea & $361,679.12$ \\
\hline
\end{tabular}

To calculate the wind turbine output, HOMER first calculates the wind speed at the hub height of the turbine. This is conducted by applying the logarithmic law, using Equation (9) [35];

$$
U_{\text {hub }}=U_{\text {anem }} \times\left(\frac{\ln \left(\frac{z_{\text {hub }}}{z_{0}}\right)}{\ln \left(\frac{z_{\text {anem }}}{z_{0}}\right)}\right)
$$

where:

$U_{h u b}=$ Hub height wind speed $(\mathrm{m} / \mathrm{s})$

$U_{\text {anem }}=$ Anemometer wind speed $(\mathrm{m} / \mathrm{s})$

$Z_{\text {hub }}=$ Hub height $(\mathrm{m})$

$Z_{\text {anem }}=$ Anemometer height $(\mathrm{m})$

$Z_{0}=$ Surface roughness length $(\mathrm{m})$

Once the hub height wind speed has been calculated, HOMER uses the power curve of each respective turbine to calculate the output, assuming that at any value above or below the minimum and maximum speeds the turbine produces no power. Since the tidal speed change is assumed to be negligible with depth, a logarithmic law is not applied to the hydrokinetic resource. As such, the hydrokinetic turbine output is calculated using the power output at the corresponding tidal speed based on the power curve of the turbine, as shown in Figure 10. 


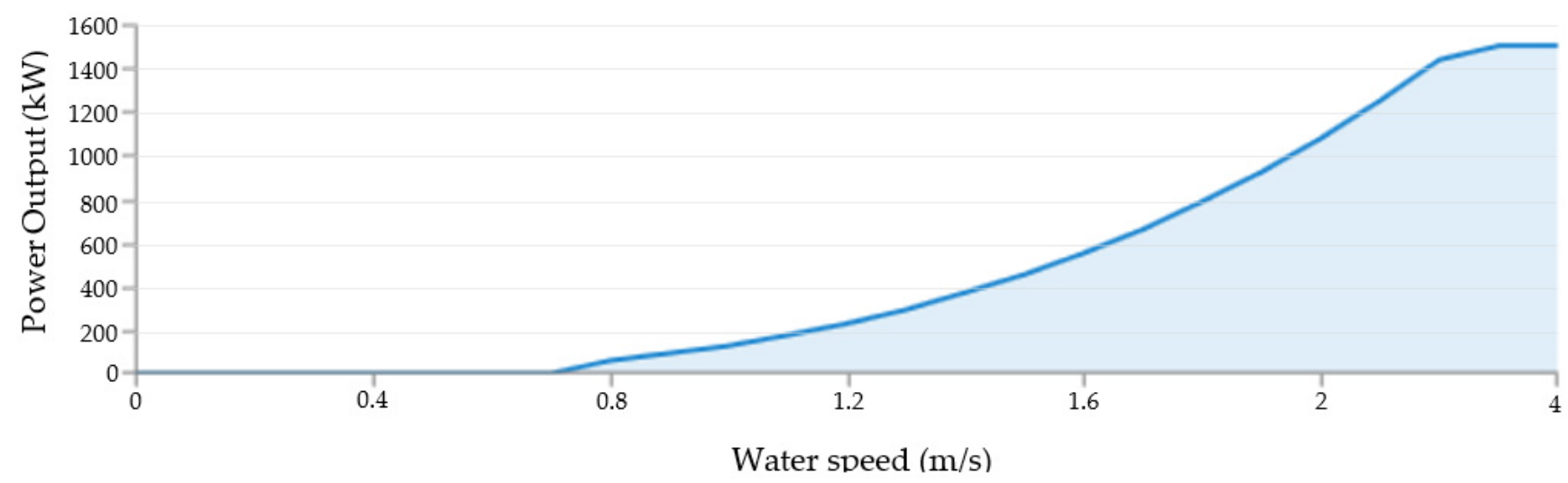

Figure 10. Hydrokinetic turbine power curve.

The solar output is calculated in an equation relating all the input values and the solar resource available. The effect of temperature is not modelled, and therefore the temperature coefficient of power is taken to be 0 . Therefore the equation used by HOMER is shown in Equation (10) [35];

$$
P_{P V}=Y_{P V} f_{P V}\left(\frac{\bar{G}_{T}}{\bar{G}_{T, S T C}}\right)
$$

where:

$P_{P V}=$ PV array output $(\mathrm{kW})$

$Y_{P V}=$ Rated capacity of PV array $(\mathrm{kW})$

$f_{P V}=\mathrm{PV}$ derating factor $(\%)$

$G_{T}=$ Solar irradiance incident on the $\mathrm{PV}$ array $\left(\mathrm{kW} / \mathrm{m}^{2}\right)$

$G_{T, S T C}=$ Incident radiation at standard test conditions $\left(\mathrm{kW} / \mathrm{m}^{2}\right)$

The HOMER Pro software was developed with an optimisation algorithm that significantly simplifies the design process for identifying the lowest Net Present Cost microgrid systems. The HOMER Optimizer is a proprietary derivative free algorithm that was developed to work specifically for HOMER. The main benefit of the Optimizer is that the user does not have to specify all the possible options that need to be simulated. This means not having to define the specific number of each component that needs to be tested. Instead, details such as the location, electrical load and cost estimates are input to the software, and then HOMER finds the required architecture to create the lowest Net Present Cost system itself. When the number of each component is input, there are a set number of combinations to be run, which is often very high. The Optimizer is significantly faster than simply inputting values, since the algorithm can identify that systems such as storage with no converter would not allow the transfer of energy, and as such are not worth pursuing further. Therefore, the algorithm only works on systems that do not have obvious flaws, until it runs to convergence to find the final values.

This capability is most noticeable when the ideal number of components such as solar panels or batteries to provide energy for whole cities is being simulated, as is the case in this study. Since a large number of panels is obviously required, user input values would either need to be very near to the actual amount required, or thousands of simulations of different combinations would be run unnecessarily. A graphical summary of the methodology is shown in Chart 1, which highlights the key objectives of environmental, economic and social improvement, along with identifying the key steps which must be considered. 


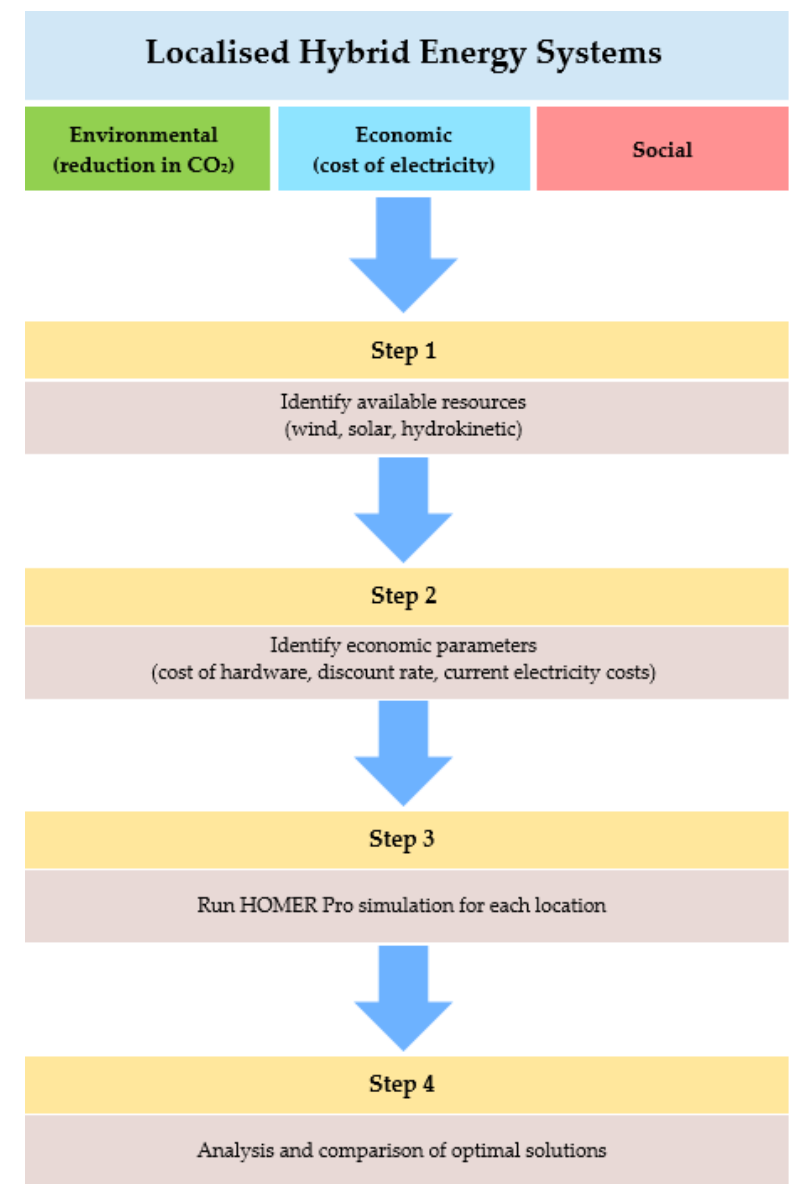

Chart 1. Summary flowchart of methodology.

\section{Results}

The full results for the lowest Net Present Cost hybrid systems are shown in Appendix B, which has results for each of the three different wind turbines separately, along with the information for the base grid system as a reference. Table 9 shows a summary of the main results generated by HOMER. In each case, the $4 \mathrm{MW}$ turbine is the choice for the lowest cost system. Table 10 shows the Base system costs, which emphasises how much cheaper the hybrid system is in the long term. All payback times throughout this report are in years.

Table 9. Results for lowest Net Present Cost hybrid systems.

\begin{tabular}{|c|c|c|c|c|c|c|}
\hline Location & $\begin{array}{l}\text { Net Present Cost } \\
(G B P, £)\end{array}$ & $\begin{array}{c}\text { Initial Capital } \\
(G B P, £)\end{array}$ & $\begin{array}{c}\text { Operating Cost } \\
(G B P, £)\end{array}$ & $\begin{array}{l}\text { Cost of Energy } \\
(\text { GBP, } £)\end{array}$ & $\begin{array}{c}\text { Payback } \\
\text { Time }\end{array}$ & $\begin{array}{c}\text { Renewable } \\
\text { Fraction }\end{array}$ \\
\hline Bournemouth & $1,025,596,000$ & $536,602,985$ & $37,825,780$ & 0.03543 & 2.28 & 92.8 \\
\hline Brighton & $651,319,500$ & $340,695,218$ & $24,028,150$ & 0.03593 & 2.30 & 94.9 \\
\hline Bristol & $1,219,563,000$ & $657,401,110$ & $43,485,680$ & 0.03415 & 2.32 & 95.2 \\
\hline Exeter & $386,684,100$ & $203,360,176$ & $14,180,910$ & 0.03471 & 2.29 & 95.1 \\
\hline Leicester & $898,865,200$ & $477,394,895$ & $32,602,570$ & 0.03473 & 2.27 & 95.3 \\
\hline Manchester & $1,743,376,000$ & $927,816,966$ & $63,087,050$ & 0.03500 & 2.27 & 95.3 \\
\hline Newcastle & $823,653,400$ & $435,016,681$ & $30,062,750$ & 0.03532 & 2.29 & 95.1 \\
\hline Plymouth & $621,136,300$ & $323,382,716$ & $23,032,540$ & 0.03554 & 2.30 & 94.9 \\
\hline Portsmouth & $614,303,400$ & $323,027,212$ & $22,531,490$ & 0.03471 & 2.29 & 95.2 \\
\hline Swansea & $623,906,600$ & $326,217,080$ & $23,027,590$ & 0.03528 & 2.30 & 95.0 \\
\hline
\end{tabular}


Table 10. Base system data.

\begin{tabular}{|c|c|c|c|c|c|c|}
\hline Location & $\begin{array}{l}\text { Net Present Cost } \\
(G B P, £)\end{array}$ & $\begin{array}{c}\text { Initial Capital } \\
(G B P, £)\end{array}$ & $\begin{array}{c}\text { Operating Cost } \\
(\mathrm{GBP}, £)\end{array}$ & $\begin{array}{l}\text { Cost of Energy } \\
(\mathrm{GBP}, \pm)\end{array}$ & $\begin{array}{l}\text { Payback } \\
\text { Time }\end{array}$ & $\begin{array}{c}\text { Renewable } \\
\text { Fraction }\end{array}$ \\
\hline Bournemouth & $3,713,235,000$ & 0 & $287,235,000$ & 0.195 & - & 0 \\
\hline Brighton & $2,339,364,000$ & 0 & $180,960,000$ & 0.195 & - & 0 \\
\hline Bristol & $4,459,411,000$ & 0 & $344,955,000$ & 0.195 & - & 0 \\
\hline Exeter & $1,396,559,000$ & 0 & $108,030,000$ & 0.195 & - & 0 \\
\hline Leicester & $3,302,334,000$ & 0 & $255,450,000$ & 0.195 & - & 0 \\
\hline Manchester & $6,412,991,000$ & 0 & $496,073,000$ & 0.195 & - & 0 \\
\hline Newcastle & $2,992,268,000$ & 0 & $231,465,000$ & 0.195 & - & 0 \\
\hline Plymouth & $2,223,403,000$ & 0 & $171,990,000$ & 0.195 & - & 0 \\
\hline Portsmouth & $2,218,362,000$ & 0 & $171,600,000$ & 0.195 & - & 0 \\
\hline Swansea & $2,238,529,000$ & 0 & $173,160,000$ & 0.195 & - & 0 \\
\hline
\end{tabular}

The architecture of each system shows the number of each component included in each hybrid system, as shown in Table 11. This shows that all of the systems utilised solely wind turbines together with converters and lithium ion batteries, except for Bristol which also has tidal turbines included within the system. As such, the percentage of energy generated from all of the systems is $100 \%$ wind power, except for Bristol which has $89.8 \%$ wind power and $10.2 \%$ tidal power, as shown in Appendix B. The split of generation methods is also true for locations with smaller demand such as Exeter, which uses solely wind turbines within the lowest Net Present Cost system.

Table 11. Architecture of lowest Net Present Cost systems.

\begin{tabular}{cccccc}
\hline Location & $\begin{array}{c}\text { Wind Turbine } \\
\text { Number }\end{array}$ & $\begin{array}{c}\text { Hydro Turbine } \\
\text { Number }\end{array}$ & $\begin{array}{c}\text { Solar Panel } \\
\text { Numbers }\end{array}$ & $\begin{array}{c}\text { Lithium ion } \\
\text { Battery (kWh) }\end{array}$ & Converter (kW) \\
\hline Bournemouth & 111 & 0 & 0 & $1,391,183$ & 228,370 \\
Brighton & 70 & 0 & 0 & 901,061 & 140,833 \\
Bristol & 126 & 42 & 0 & $1,326,536$ & 231,752 \\
Exeter & 43 & 0 & 0 & 513,315 & 85,120 \\
Leicester & 98 & 0 & 0 & $1,248,090$ & 204,689 \\
Manchester & 188 & 0 & 0 & $2,469,768$ & 398,196 \\
Newcastle & 89 & 0 & 0 & $1,131,594$ & 191,628 \\
Plymouth & 68 & 0 & 0 & 833,792 & 130,511 \\
Portsmouth & 68 & 0 & 819,750 & 135,738 \\
Swansea & 69 & & & 832,060 & 132,416 \\
\hline
\end{tabular}

A fully detailed breakdown of the initial capital costs for each hybrid system is also given in Appendix B, with two cases being shown in Figures 11 and 12. Figure 11 shows the breakdown for Manchester, including costs for the wind turbines, converter and lithium ion battery storage. All of the simulated locations except for Bristol have similar breakdowns to Manchester in that HOMER calculated that the lowest Net Present Cost system was made up solely from these three generation and storage components. Figure 12 shows the breakdown for Bristol, which also includes tidal turbines within the lowest Net Present Cost system.

The emissions produced by each component for each system are shown in Appendix B. This has been manipulated to show the cost per tonne of $\mathrm{CO}_{2}$ saved using the calculations detailed in the Methodology section. The calculated values are shown in Table 12, which shows the cost for the lowest Net Present Cost system, the 4 MW turbine, along with the two other types of turbine. The data show that while the $4 \mathrm{MW}$ turbine has the lowest Net Present Cost system and the highest renewable fraction, the $2.5 \mathrm{MW}$ turbine has the lowest cost for the removal of $\mathrm{CO}_{2}$. The explanation for this comes from the emissions associated with the large number of lithium ion batteries required for the $4 \mathrm{MW}$ and $900 \mathrm{~kW}$ turbines, as opposed to the $2.5 \mathrm{MW}$ turbine which has very few batteries. 


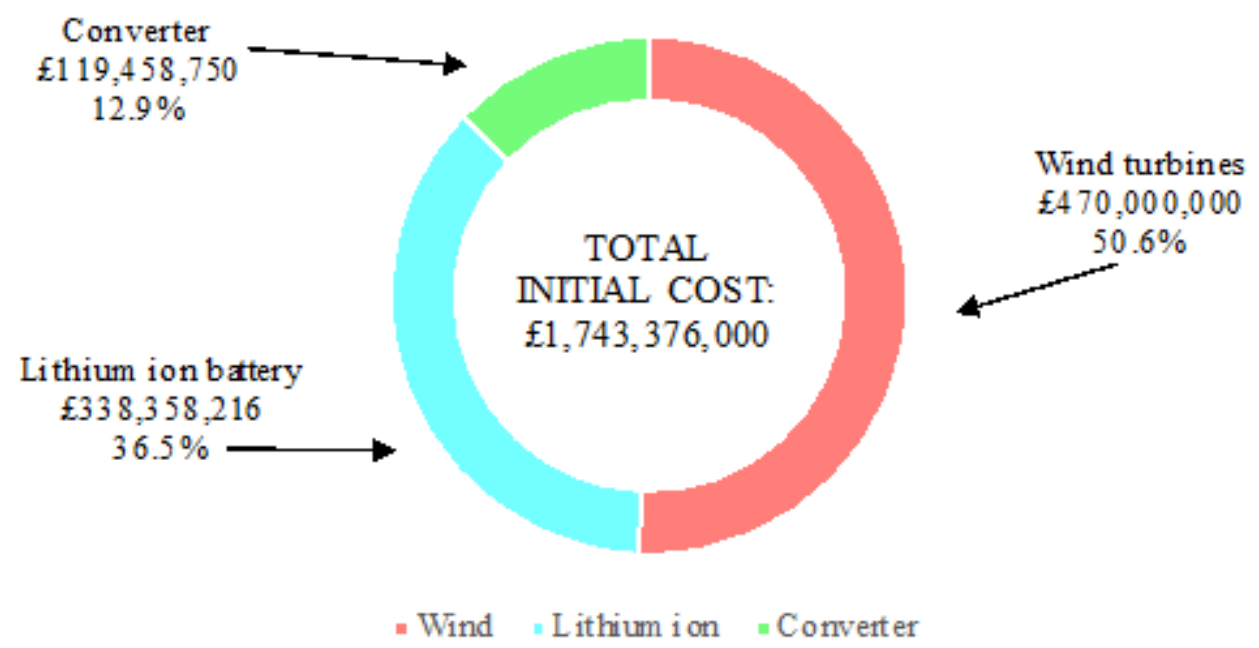

Figure 11. Initial capital breakdown for Manchester.

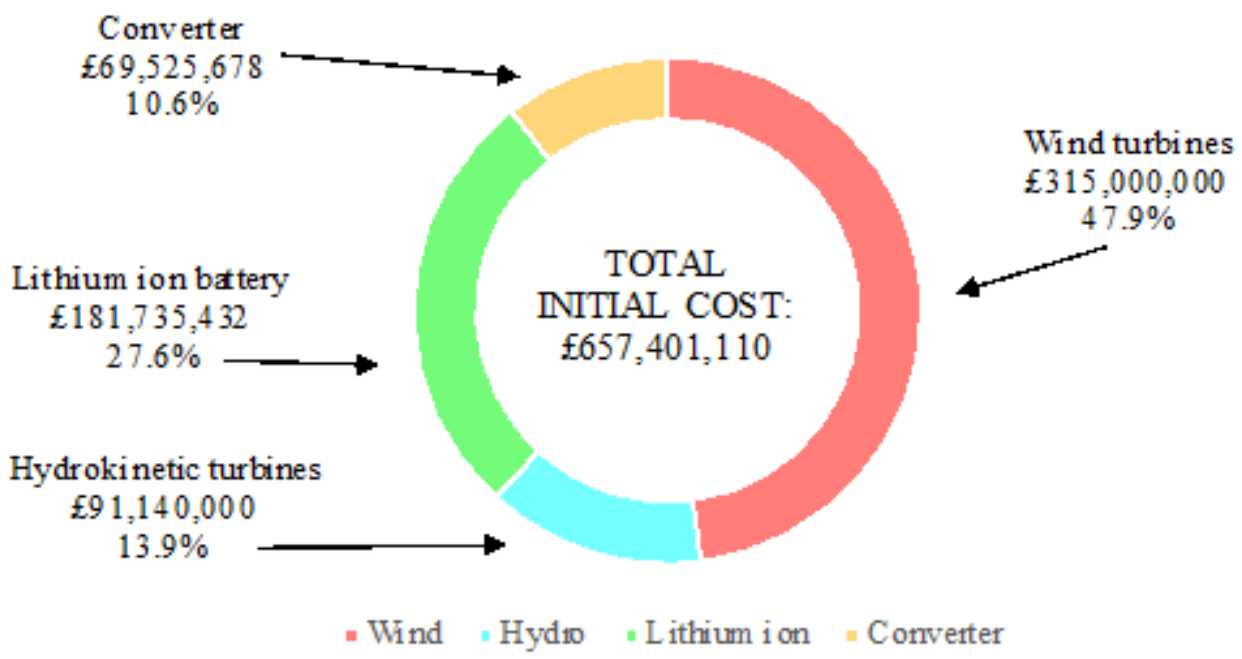

Figure 12. Initial capital breakdown for Bristol.

Table 12. Cost per tonne of emissions saved.

\begin{tabular}{|c|c|c|c|}
\hline Location & $\begin{array}{c}\text { Lowest Net Present Cost } \\
(4 \mathrm{MW}) \\
(\mathrm{GBP}, £)\end{array}$ & $\begin{array}{l}2.5 \text { MW Turbine } \\
(\text { GBP, } £)\end{array}$ & $\begin{array}{c}900 \mathrm{~kW} \text { Turbine } \\
(\mathrm{GBP}, £)\end{array}$ \\
\hline Bournemouth & $4,460.19$ & $3,121.30$ & $3,996.04$ \\
\hline Brighton & $4,477.29$ & $3,146.82$ & $4,065.28$ \\
\hline Bristol & $4,203.73$ & $3,025.11$ & $3,686.15$ \\
\hline Exeter & $3,981.56$ & $3,315.06$ & $4,531.00$ \\
\hline Leicester & $4,324.43$ & $3,049.13$ & $3,951.20$ \\
\hline Manchester & $4,245.00$ & $3,035.20$ & $3,971.43$ \\
\hline Newcastle & $4,340.04$ & $3,098.01$ & $3,995.43$ \\
\hline Plymouth & $4,584.95$ & $3,179.27$ & $4,042.48$ \\
\hline Portsmouth & $4,440.16$ & $3,128.17$ & $3,989.52$ \\
\hline Swansea & $4,259.77$ & $3,174.24$ & $4,021.90$ \\
\hline
\end{tabular}

The results for systems simulating each generation method individually are given in Appendix C. Figure 13 shows a comparison between the Net Present Cost of the hybrid systems compared to each individual system. It can be seen that the hybrid system dramatically reduces the Net Present Cost, by a factor of between $72 \%$ and $73 \%$ for each location. For all of the systems except for Bristol, the lowest Net Present Cost hybrid system is the same as that of wind turbine only. For each location, the solar only systems were 
cheaper than the base grid system cost; however, they were considerably more expensive than the wind only or hybrid systems. For the hydro turbine only systems, there is a large range in terms of the Net Present Cost. For Bristol and Portsmouth, the hydro only systems are cheaper than the solar systems, while in Swansea the hydro only system is more expensive than solar only but cheaper than the current base system. For all other locations, the tidal resource is not sufficient to generate electricity consistently, and therefore the base system cost is taken.

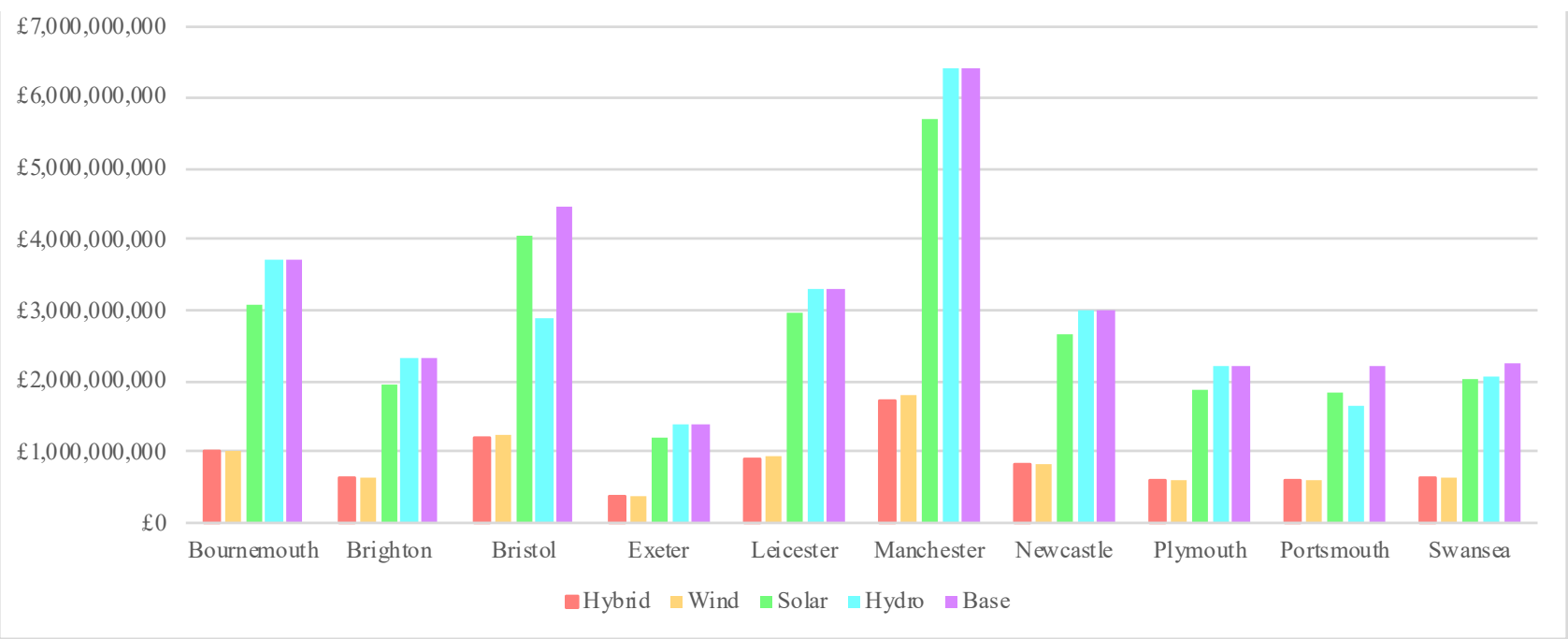

Figure 13. Net Present Cost comparisons between systems.

The results do rely heavily on the availability of renewable resources. With the object of the paper to assess which generation methods best satisfy the electrical demand of each specific location, it is clear that the effectiveness of each generation method can vary significantly, and as such, system architecture must be tailored to each location.

\section{Discussion}

While the long-term financial benefit is shown clearly in all systems, both in terms of Net Present Cost and also Operating Cost, each system still requires a large initial capital expenditure. This expenditure equates to almost twice the amount of the base system annual operating cost. Despite the financial benefits being clear, finding such large amounts of capital requires significant investment, potential subsidies and even potential policy changes at the governmental level to encourage the investment further.

This is an even greater consideration when the time lag of construction is considered, as the base system will have to be used during the entire construction phase, even though the initial capital payment may have been made. Depending on the size of the installation, this can represent a significant amount. The lowest Net Present Cost systems all use the $4 \mathrm{MW}$ wind turbine as opposed to the smaller $2.5 \mathrm{MW}$ and $900 \mathrm{~kW}$ turbines. While the system using the larger turbine produces more energy in fewer turbines and for a lower Net Present Cost, far greater infrastructure is required to enable the increased energy produced to be effectively harvested. This is made possible through the lithium ion battery. However, the use of these batteries incurs a high environmental cost in terms of the mining which has to take place to make this storage method feasible. The environmental degradation caused by mining raises questions as to the long-term sustainability of batteries as a storage method, and also increases the importance of investment in other storage methods such as gravitational storage. By making these less environmentally damaging storage methods financially competitive, the emissions created by the entire generation system can be greatly reduced.

The battery also increases the financial cost substantially, and as such, the cost of energy. As shown in Appendix B, the cost of energy for the system that simulates the 
2.5 MW turbine is consistently lower than that of the $4 \mathrm{MW}$ turbine, which is due to the very low amount of batteries required for the $2.5 \mathrm{MW}$ turbine. The choice of system depends on the object of the specific location, since the $2.5 \mathrm{MW}$ turbine system will generate energy more cheaply and this will mean a higher rate of return on investment; however, the $4 \mathrm{MW}$ turbine system will satisfy more of the electrical demand for a lower longterm cost. The ecological and environmental effects of construction must be considered, and the most relevant system must be chosen based on the environmental goals of the project. The installation and successful operation of hydrokinetic and wind turbines require strong foundations to be made. For wind turbines, this is usually in the form of concrete foundations, while for hydrokinetic turbines a steel monopile is driven deep into the sea floor. In each case, animal habitats can be badly affected if care is not taken.

There are new technologies emerging within the tidal energy generation industry that could significantly reduce the effect of turbine foundation disturbance. A company called Orbital Marine [44] is developing a floating platform with hydrokinetic turbines fixed underneath, held in the current stream by anchors and greatly decreasing the ecological effect compared to steel monopiles. Companies such as Equinor are developing similar technology with floating offshore wind turbines [45]; however, it is difficult to reduce the foundations and construction required for onshore wind turbines. Instead, the specific locations of the turbines must be of greater importance, with efforts made to avoid wildlife corridors or areas with thriving and healthy ecological systems.

While solar panels represent the highest Net Present Cost solutions in many cases, they can be installed directly on to buildings and as such do not require large natural areas to be used in some cases. The amount of solar panels used in the solar only systems would require more space than just roofs to be used; however, the construction and foundations required for solar panels are significantly less than that for hydrokinetic or wind turbines. For each system, a certain area is required in which to install the generation and storage equipment. This area varies based on the size of the electrical demand being satisfied, since this contributes to whether a large or small number of each component is required. The spacing required for wind turbines is generally considered to be between 5 and 7 times the rotor diameter $[46,47]$. For this report, a value of 6 rotor diameters is used to calculate the area required. The rotor diameter of an Enercon $4 \mathrm{MW}$ turbine is $127 \mathrm{~m} \mathrm{[48],} \mathrm{meaning}$ spacing of $762 \mathrm{~m}$ is required around each side of the wind turbine.

The spacing for tidal turbines has to be greater in relative terms due to wake effects and turbulence. As such, the spacing has to be a minimum of 10 rotor diameters; otherwise, there are significant effects on power production [49]. The AR1500 hydro turbine has a rotor diameter of $18 \mathrm{~m}$ [50], meaning a spacing of at least $180 \mathrm{~m}$ is required to reduce wake effects.

The Tesla Megapack has a capacity of $2529 \mathrm{kWh}$, and a floor area of $11.89 \mathrm{~m}^{2}$ per $2529 \mathrm{~kW}$ [51]. The required area for each component is shown in Table 13. This area is calculated by designing an array of the number of required turbines, then multiplying the hypothetical lengths of the sides of the array. The area of the converter is assumed to be negligible.

Analysis of the required areas shows that the lithium ion battery space required is always feasible, since the area required is less than that of a football pitch, except for in Manchester, which would require one-and-a-half pitches worth of area.

The area required for the tidal turbines in the Bristol simulation is also feasible. The width of the channel at the location of Avonmouth is roughly $8 \mathrm{~km}$, and there are thus a large number of tidal turbine array shapes that would easily cover the required area of $1.36 \mathrm{~km}^{2}$. As an example, an array of $6 \times 7$ turbines could be used, which would keep the turbines to a select area of $1080 \mathrm{~m} \times 1260 \mathrm{~m}$. This would be a beneficial layout for a number of reasons; firstly, because it keeps the turbines closest to the highest tidal resource, and secondly because it does not interfere as much with the other operations within the channel, such as ship movements. By having a select area of turbines rather than a long line, the turbine array can avoid shipping activities. For the wind turbines, the areas required are far 
greater and as such create more difficulty in finding acceptable locations. In reality, turbines will have to be placed at multiple different sites surrounding each location, as opposed to having one specific location at which all the turbines are placed. Consideration will also need to be taken with regard to national parks or areas of outstanding natural beauty, because while these may provide plenty of space to build turbines, they are protected areas and as such are generally not feasible to use for turbine construction.

Table 13. Required areas for system components.

\begin{tabular}{cccc}
\hline Location & $\begin{array}{c}\text { Wind Turbine Area } \\
\mathbf{( k m}^{\mathbf{2}}\end{array}$ & $\begin{array}{c}\text { Hydro Turbine Area } \\
\left.\mathbf{( k m}^{\mathbf{2}}\right)\end{array}$ & $\begin{array}{c}\text { Lithium Ion Battery } \\
\text { Area } \mathbf{( m}^{\mathbf{2}} \mathbf{)}\end{array}$ \\
\hline Bournemouth & 64.5 & 0 & 6542 \\
Brighton & 40.6 & 0 & 4237 \\
Bristol & 73.2 & 1.36 & 6238 \\
Exeter & 23.4 & 0 & 2423 \\
Leicester & 56.9 & 0 & 5869 \\
Manchester & 109.2 & 0 & 11,613 \\
Newcastle & 51.7 & 0 & 5231 \\
Plymouth & 39.5 & 0 & 3921 \\
Portsmouth & 39.5 & 0 & 3855 \\
Swansea & 40.1 & 0 & 3913 \\
\hline
\end{tabular}

\section{Conclusions}

The analysis has proved that hybrid energy systems consisting of multiple different generation methods at specific locations around the UK can successfully supply the power load required at a notably lower Net Present Cost than the base grid system. The most effective generation for each comes solely from wind turbines, with the exception of Bristol, which also utilises hydrokinetic turbines. All of the lowest Net Present Cost systems also utilised a lithium ion battery and converter within the system architecture. The trend also showed that the larger the wind turbine, the lower the Net Present Cost due to the economies of scale associated with larger turbines. At each location, the solar energy generation had a lower Net Present Cost than the base system. However, this was still significantly higher than the wind turbine systems.

Author Contributions: Conceptualization, C.N., M.A.; methodology, C.N.; software, M.A.; validation, M.A., C.N.; formal analysis, C.N., M.A., M.D; investigation, M.A., M.D; resources, M.A.; data curation, C.N., M.A.; writing—original draft preparation, C.N.; writing—review and editing, M.A., M.D.; visualization, C.N., M.A.; supervision, M.A.; project administration, M.A. All authors have read and agreed to the published version of the manuscript.

Funding: This research received no external funding from funding agencies in the public, commercial or not-for-profit sectors.

Institutional Review Board Statement: Not applicable.

Informed Consent Statement: Not applicable.

Acknowledgments: The authors would like to appreciate the anonymous reviewers for their insightful comments and suggestions.

Conflicts of Interest: The authors declare no conflict of interest. 


\section{Appendix A}

\begin{tabular}{|c|c|c|c|c|c|c|c|c|c|c|c|c|c|c|c|c|c|c|c|c|}
\hline \multirow{4}{*}{ Time step } & \multicolumn{16}{|c|}{ Locations tidal speed data } & \multirow{3}{*}{\multicolumn{2}{|c|}{\begin{tabular}{|c|} 
Leicester \\
Speed (knots) \\
\end{tabular}}} & & \\
\hline & \multicolumn{4}{|c|}{ Bournemouth } & \multicolumn{4}{|c|}{ Brighton } & \multicolumn{4}{|c|}{ Bristol } & \multicolumn{4}{|c|}{ Exeter } & & & \multirow{2}{*}{\multicolumn{2}{|c|}{$\begin{array}{l}\text { Manchester } \\
\text { Speed (m/s) }\end{array}$}} \\
\hline & \multicolumn{2}{|c|}{ Speed (knots) } & \multicolumn{2}{|c|}{ Speed $(\mathrm{m} / \mathrm{s})$} & \multicolumn{2}{|c|}{ Speed (knots) } & \multicolumn{2}{|c|}{ Speed $(\mathrm{m} / \mathrm{s})$} & \multicolumn{2}{|c|}{ Speed (knots) } & \multicolumn{2}{|c|}{ Speed $(\mathrm{m} / \mathrm{s})$} & \multicolumn{2}{|c|}{ Speed (knots) } & \multicolumn{2}{|c|}{ Speed $(\mathrm{m} / \mathrm{s})$} & & & & \\
\hline & Springs & Neaps & Springs & Neaps & Springs & Neaps & Springs & Neaps & Springs & Neaps & Springs & Neaps & Springs & Neaps & Springs & Neaps & Springs & Neaps & Springs & Neaps \\
\hline 6B & 6 & 11 & 0.309 & 0.566 & 3 & 5 & 0.154 & 0.257 & 23 & 43 & 1.183 & 2.212 & 3 & 5 & 0.154 & 0.257 & \multirow{12}{*}{ NA } & \multirow{12}{*}{ NA } & \multirow{12}{*}{$\mathrm{NA}$} & \multirow{12}{*}{ NA } \\
\hline 4B & 17 & 33 & 0.875 & 1.698 & 9 & 19 & 0.463 & 0.977 & 9 & 16 & 0.463 & 0.823 & 4 & 8 & 0.206 & 0.412 & & & & \\
\hline 3B & 18 & 37 & 0.926 & 1.903 & 13 & 26 & 0.669 & 1.338 & 6 & 11 & 0.309 & 0.566 & 3 & 7 & 0.154 & 0.360 & & & & \\
\hline 2B & 14 & 28 & 0.720 & 1.440 & 14 & 25 & 0.720 & 1.286 & 16 & 30 & 0.823 & 1.543 & 2 & 4 & 0.103 & 0.206 & & & & \\
\hline 1B & 6 & 12 & 0.309 & $\mid 0.617$ & 9 & 17 & 0.463 & 0.875 & 20 & 38 & 1.029 & 1.955 & 1 & 1 & 0.051 & 0.051 & & & & \\
\hline HW & 2 & 5 & 0.103 & 0.257 & 3 & 5 & 0.154 & 0.257 & 20 & 37 & 1.029 & 1.903 & 2 & 3 & 0.103 & 0.154 & & & & \\
\hline $1 \mathrm{~A}$ & 9 & 19 & 0.463 & \begin{tabular}{|l|} 
\\
\end{tabular} & 4 & 8 & 0.206 & 0.412 & 20 & 37 & 1.029 & 1.903 & 4 & 7 & 0.206 & 0.360 & & & & \\
\hline $2 \mathrm{~A}$ & 16 & 32 & 0.823 & 1.646 & 10 & 19 & 0.514 & 0.977 & 17 & 32 & 0.875 & 1.646 & 5 & 9 & 0.257 & 0.463 & & & & \\
\hline $3 \mathrm{~A}$ & 18 & 36 & 0.926 & 1.852 & 13 & 25 & 0.669 & 1.286 & 7 & 13 & 0.360 & 0.669 & 5 & 10 & 0.257 & 0.514 & & & & \\
\hline $4 \mathrm{~A}$ & 13 & 27 & 0.669 & 1.389 & 13 & 22 & 0.669 & 1.132 & 18 & 34 & 0.926 & 1.749 & 3 & 6 & 0.154 & 0.309 & & & & \\
\hline $5 \mathrm{~A}$ & 5 & 11 & 0.257 & $\mid$\begin{tabular}{|l|} 
\\
\end{tabular} & 11 & 19 & 0.566 & 0.977 & 31 & 58 & 1.595 & 2.984 & 1 & 2 & 0.051 & 0.103 & & & & \\
\hline $6 \mathrm{~A}$ & 3 & 6 & 0.154 & \begin{tabular}{|l|} 
\\
\end{tabular} & 6 & 11 & 0.309 & 0.566 & 26 & 48 & 1.338 & 2.469 & 2 & 4 & 0.103 & 0.206 & & & & \\
\hline $\begin{array}{l}\text { CALCULATED } \\
\text { AVERAGE }\end{array}$ & \multicolumn{2}{|c|}{ Not required } & 0.072 & 0.797 & \multicolumn{2}{|l|}{ lot $\mathrm{re}$} & 0 & 0.297 & Not re & quired & 0.3577 & 2.335 & \multicolumn{2}{|c|}{ Not required } & 0 & 0 & NA & NA & NA & NA \\
\hline
\end{tabular}

\begin{tabular}{|c|c|c|c|c|c|c|c|c|c|c|c|c|c|c|c|c|}
\hline \multirow{4}{*}{ Time step } & \multicolumn{16}{|c|}{ Locations tidal data } \\
\hline & \multicolumn{4}{|c|}{ Newcastle } & \multicolumn{4}{|c|}{ Plymouth } & \multicolumn{4}{|c|}{ Portsmouth } & \multicolumn{4}{|c|}{ Swansea } \\
\hline & \multicolumn{2}{|c|}{ Speed (knots) } & \multicolumn{2}{|c|}{ Speed $(\mathbf{m} / \mathbf{s})$} & \multicolumn{2}{|c|}{ Speed (knots) } & \multicolumn{2}{|c|}{ Speed $(\mathrm{m} / \mathrm{s})$} & \multicolumn{2}{|c|}{ Speed (knots) } & \multicolumn{2}{|c|}{ Speed $(\mathrm{m} / \mathrm{s})$} & \multicolumn{2}{|c|}{ Speed (knots) } & \multicolumn{2}{|c|}{ Speed $(\mathrm{m} / \mathrm{s})$} \\
\hline & Springs & Neaps & Springs & Neaps & \begin{tabular}{|l} 
Springs \\
\end{tabular} & Neaps & Springs & Neaps & Springs & Neaps & Springs & Neaps & Springs & Neaps & \begin{tabular}{|l} 
Springs \\
\end{tabular} & Neaps \\
\hline 6B & 7 & 13 & 0.360 & \begin{tabular}{|l|}
0.669 \\
\end{tabular} & 11 & 22 & 0.566 & 1.132 & 6 & 12 & 0.309 & 0.617 & 12 & 26 & 0.617 & \begin{tabular}{|l|}
1.338 \\
\end{tabular} \\
\hline $5 \mathrm{~B}$ & 3 & 5 & 4 & 0.257 & 16 & 20 & 0.514 & 1.029 & 18 & 36 & 0.926 & 1.852 & 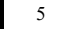 & 10 & 0.257 & 0.514 \\
\hline 4B & 1 & 2 & 0.051 & 0.103 & 10 & 21 & 0.514 & 1.080 & 22 & 45 & 1.132 & 2.315 & 6 & 13 & 0.309 & 0.669 \\
\hline 3B & 4 & 8 & 6 & 0.4 & 7 & 13 & 0.360 & 0.669 & 22 & 45 & 1.132 & 2.315 & 17 & 37 & 0.875 & 1.903 \\
\hline $2 \mathrm{~B}$ & 7 & 12 & 0.360 & 0.617 & 14 & 29 & 0.720 & 1.492 & 17 & 35 & 0.875 & 1.801 & 21 & 46 & 1.080 & 2.366 \\
\hline $1 \mathrm{~B}$ & 9 & 16 & 0.463 & 0.823 & 13 & 30 & 0.772 & 1.543 & 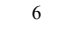 & 13 & 0.309 & 0.669 & 18 & 39 & 0.926 & 2.006 \\
\hline HW & 6 & 11 & 0.309 & $\mid 0.566$ & 12 & 25 & 0.617 & 1.286 & 6 & 12 & 09 & 0.617 & 12 & 25 & 0.617 & 1.286 \\
\hline $1 \mathrm{~A}$ & 4 & 7 & 0.206 & 0.360 & 11 & 22 & 0.566 & 1.132 & 19 & 39 & 0.977 & 2.006 & 6 & 13 & 0.309 & 0.669 \\
\hline 2 & 0 & 0 & & & . & 18 & 0.463 & 0.926 & 21 & 4 & 0 & 2.2 & 4 & 8 & 0.206 & 0.412 \\
\hline $3 A$ & 4 & 7 & 0. & 0.3 & 5 & 10 & 0.257 & 0.514 & 20 & 41 & 1.029 & 2.109 & 13 & 27 & 0.669 & 1.389 \\
\hline $4 \mathrm{~A}$ & 7 & 13 & 0.360 & 0.669 & 2 & 3 & 0.103 & 0.154 & 15 & 31 & 0.772 & 1.595 & 17 & 37 & 0.875 & 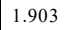 \\
\hline $5 \mathrm{~A}$ & 8 & 14 & 0.412 & 0.720 & 10 & 21 & 0.514 & 1.080 & 6 & 12 & 0.309 & 0.617 & 18 & 38 & 0.926 & $\mid 1.955$ \\
\hline $6 \mathrm{~A}$ & 6 & 12 & 0.309 & \begin{tabular}{|l|}
0.617 \\
\end{tabular} & 11 & 22 & 0.566 & 1.132 & 4 & 7 & 0.206 & 0.360 & 14 & 31 & 0.720 & \begin{tabular}{|l|} 
\\
\end{tabular} \\
\hline $\begin{array}{r}\text { CALCULATE } \\
\text { AVERAGE }\end{array}$ & \multicolumn{2}{|c|}{ Not required } & 0 & 0.014 & \multicolumn{2}{|c|}{ Not required } & 0 & 0.458 & \multicolumn{2}{|c|}{ Not required } & 0.196 & 1.778 & \multicolumn{2}{|c|}{ Not required } & 0.107 & \begin{tabular}{|l|}
1.381 \\
\end{tabular} \\
\hline
\end{tabular}




\section{Appendix B}

\begin{tabular}{|c|c|c|c|c|c|c|c|c|c|c|c|c|c|c|c|c|c|c|c|c|c|}
\hline & & & & & & & & & & & & & & & & & & & & & \\
\hline Location & Wind turbine used & NPC & $\mathrm{COE}$ & Operating cost $/ y r$ & \begin{tabular}{|l|l|} 
Initital capital \\
\end{tabular} & 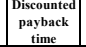 & 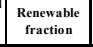 & Wind & Hydro & Solar & ititium ion & Converter & Wind & Hydro & Solar & Lithium ion & Comenter & Wind & Hydro & Solar & Tha \\
\hline urnemouth & 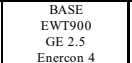 & & 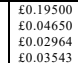 & & $\begin{array}{l}2109 \\
2199\end{array}$ & & 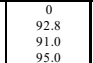 & $\begin{array}{c}403 \\
106 \\
111 \\
11\end{array}$ & & & 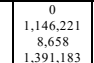 & 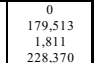 & 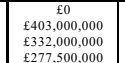 & & & $\begin{array}{l}77 \\
67 \\
n_{1}\end{array}$ & $\begin{array}{l}3.3 \\
3.4 \\
14 \\
14\end{array}$ & & & & \\
\hline Brighton & 甚, & & 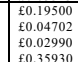 & 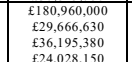 & 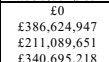 & 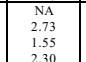 & 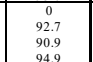 & $\begin{array}{c}245 \\
105 \\
70\end{array}$ & & & 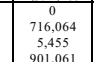 & 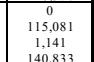 & 衤o & & 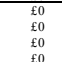 & 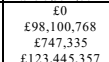 & $\begin{array}{l}179 \\
119 \\
819\end{array}$ & $\begin{array}{l}301 \\
3.11 \\
1.17\end{array}$ & & & \\
\hline Britiol & 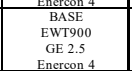 & 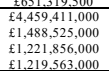 & 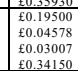 & 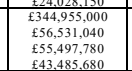 & 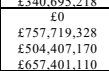 & $\begin{array}{l}2.84 \\
2.84 \\
1.35 \\
2.32\end{array}$ & 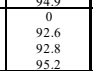 & $\begin{array}{l}403 \\
412 \\
126 \\
126\end{array}$ & $\begin{array}{l}60 \\
60 \\
42 \\
42\end{array}$ & & 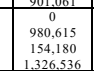 & 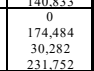 & 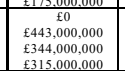 & 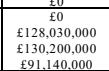 & & 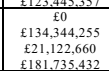 & 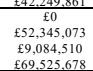 & & & & \\
\hline Extert & 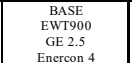 & 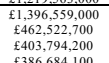 & 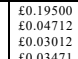 & 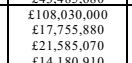 & 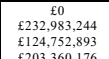 & 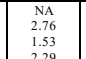 & $\begin{array}{l}0.7 \\
92.7 \\
90.8 \\
9.8\end{array}$ & $\underbrace{1,53}_{62}$ & & & 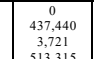 & 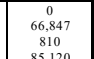 & 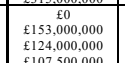 & $8 \mathrm{f0}$ & & 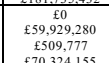 & 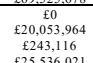 & & & & \\
\hline Leicester & 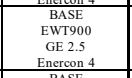 & 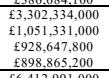 & 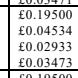 & 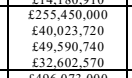 & 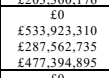 & $\begin{array}{l}2.65 \\
\text { i.48 } \\
2.27 \\
2.24\end{array}$ & 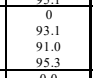 & $\begin{array}{l}.0 \\
\text { s.49 } \\
\text { and } \\
98 \\
98\end{array}$ & & & 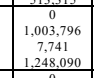 & 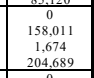 & 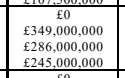 & & $t$ & 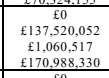 & 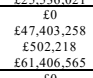 & & & & \\
\hline Vuncheser & & & 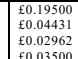 & 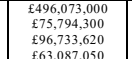 & 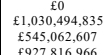 & $\begin{array}{l}2.02 \\
1.45 \\
2,27\end{array}$ & $\begin{array}{l}93.4 \\
90.8 \\
95.3\end{array}$ & 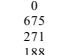 & & & 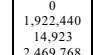 & 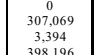 & 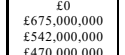 & & & 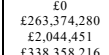 & & & & & \\
\hline Nencastle & C:B & 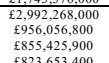 & 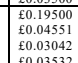 & & 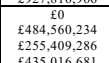 & $\begin{array}{l}2.66 \\
1.47 \\
1.20\end{array}$ & $\begin{array}{l}9.1 .1 \\
90.5 \\
90.5\end{array}$ & $\begin{array}{l}30 \\
\text { 3117 } \\
1.72\end{array}$ & & & 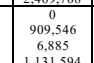 & 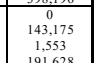 & 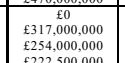 & & 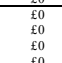 & & & & & & \\
\hline Plymouth & & 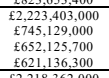 & 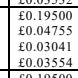 & 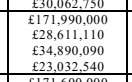 & 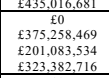 & 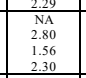 & 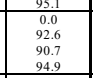 & $\begin{array}{l}89 \\
247 \\
100 \\
68 \\
68\end{array}$ & & & 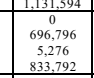 & 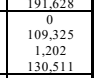 & & 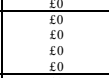 & 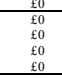 & 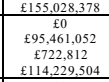 & & & & & \\
\hline tsmouth & 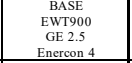 & & to. & & 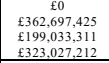 & 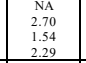 & 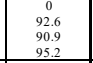 & $\begin{array}{r}209 \\
299 \\
98 \\
68\end{array}$ & & & 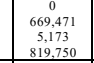 & 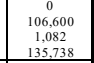 & & 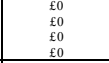 & 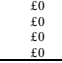 & 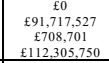 & 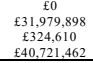 & & & & \\
\hline swanese. & 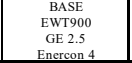 & 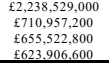 & 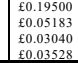 & 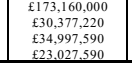 & 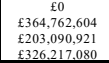 & 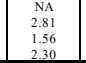 & $\begin{array}{l}0.0 \\
9.60 \\
0.07 \\
0.0\end{array}$ & $\begin{array}{l}205 \\
240 \\
69 \\
69 \\
\end{array}$ & & & 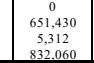 & 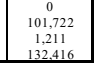 & 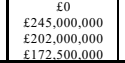 & f0 & 促 & 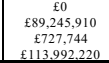 & 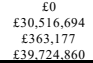 & 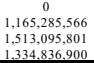 & & & \\
\hline
\end{tabular}

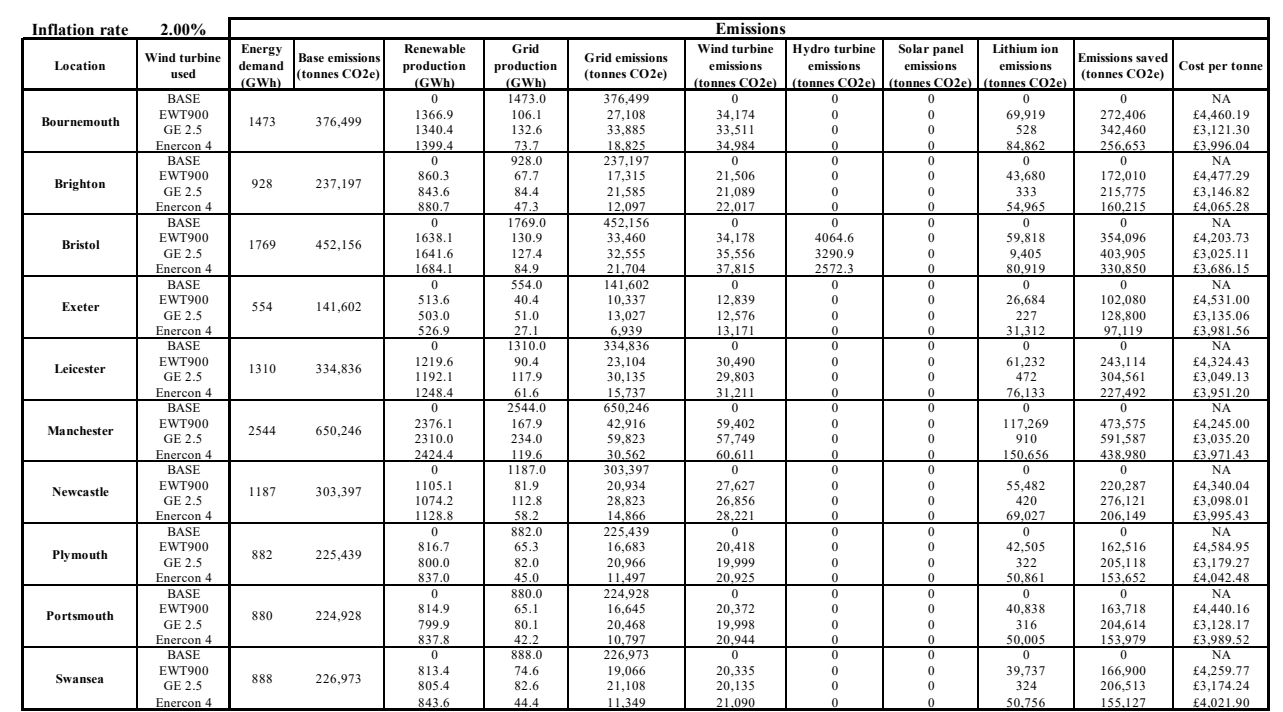




\section{Appendix C}

\begin{tabular}{|c|c|c|c|c|c|c|c|c|c|c|c|c|c|c|c|c|c|c|c|c|c|}
\hline \multirow{2}{*}{$\begin{array}{c}\text { Inflation rate } \\
\text { Locations }\end{array}$} & \multirow{2}{*}{\begin{tabular}{|c|}
$2.00 \%$ \\
Generation \\
\end{tabular}} & \multicolumn{3}{|c|}{$\begin{array}{l}\text { Architecture } \\
\end{array}$} & \multicolumn{4}{|c|}{ Initial capital } & \multicolumn{6}{|c|}{ System information } & \multicolumn{7}{|c|}{ 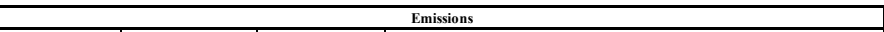 } \\
\hline & & Number & Lithium ion & \begin{tabular}{|l|l} 
Converter \\
\end{tabular} & Generation & Lithium ion & Converter & Total & NPC & COE & Operating cost / yr & Initial capital & 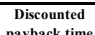 & $\begin{array}{l}\text { Renewable } \\
\text { fration }\end{array}$ & \begin{tabular}{|l|l|} 
Energy demand \\
GWwhw
\end{tabular} & $\begin{array}{c}\text { Renewable } \\
\end{array}$ & $\begin{array}{l}\text { Grid base CO2 } \\
\text { (rid }\end{array}$ & Generation Co & $\begin{array}{l}\text { Lithium in } \mathrm{CO}^{2} \\
\text { ittum }\end{array}$ & $\begin{array}{l}\text { Emissions saved } \\
\text { (fssesc } 02020\end{array}$ & Cost per tonne \\
\hline \multirow{4}{*}{ Bournemouth } & \begin{tabular}{|l|l|} 
EWT 900 \\
\end{tabular} & & 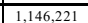 & \begin{tabular}{|l|l|}
179,513 \\
\end{tabular} & $f_{f 403,000,000}$ & $87.032,277$ & $\{55,853,933$ & $6613,886,210$ & $1,214,982,000$ & $\begin{array}{c}f 0.0465 \\
\end{array}$ & $\varepsilon_{\varepsilon 6,497,410}$ & ${ }^{f 613.886 .210}$ & & & \multirow{4}{*}{147} & & & & & & \\
\hline & & & & & & & & & & & & & 1.54 & (9.6 & & 1304 & $\begin{array}{l}57,4799 \\
376,499\end{array}$ & 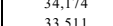 & $\begin{array}{l}69,19 \\
6,52\end{array}$ & $\begin{array}{l}272,406 \\
32460\end{array}$ & 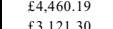 \\
\hline & ercon 4 & 111 & \begin{tabular}{|l|l|}
$1,390,1,183$ \\
\end{tabular} & \begin{tabular}{|l|}
228,370 \\
\end{tabular} & 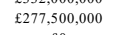 & 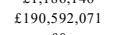 & $668,510,914$ & $€ 536,602,985$ & $1,025,596,000$ & 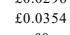 & 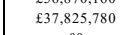 & t536,602,985 & 2.28 & 95.0 & & 1399.4 & 376,499 & $\begin{array}{l}33,911 \\
34,984\end{array}$ & 84,862 & $\begin{array}{l}524,460 \\
256,653\end{array}$ & 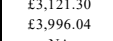 \\
\hline & \begin{tabular}{|c|}
$\begin{array}{c}\text { Al15000 } \\
\text { Solar }\end{array}$ \\
\end{tabular} & $\begin{array}{c}0 \\
992.376 \\
\end{array}$ & $\begin{array}{l}0 \\
2,132,621\end{array}$ & \begin{tabular}{|c|}
0 \\
240.922 \\
\end{tabular} & $\begin{array}{l}\mathfrak{f} 0 \\
\{832.504 .407\end{array}$ & $\begin{array}{c}\mathfrak{f} 0 \\
\{292.169 .077\end{array}$ & $\begin{array}{c}\mathrm{E} 0 \\
\mathbf{E} 72.276 .475\end{array}$ & $\begin{array}{c}£ 0 \\
£ 1,196,949.960\end{array}$ & $\begin{array}{c}\epsilon_{0} \\
\epsilon 3,07,096,000\end{array}$ & 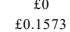 & $\begin{array}{c}£ 0 \\
€ 145,360,220\end{array}$ & $\begin{array}{c}f 0 \\
f 1.196 .949,960 \\
f\end{array}$ & $\begin{array}{c}0 \\
10.93 \\
\end{array}$ & $\begin{array}{c}0 \\
56.9\end{array}$ & & $\begin{array}{c}0 \\
838.1\end{array}$ & $\begin{array}{l}\begin{array}{l}376,4,49 \\
37,699\end{array} \\
3\end{array}$ & $\begin{array}{c}0 \\
48.612\end{array}$ & $\begin{array}{c}0 \\
130.090\end{array}$ & $\begin{array}{l}0 \\
197.797\end{array}$ & $\begin{array}{c}\mathrm{NA} \\
\mathrm{f} 15.551 .79\end{array}$ \\
\hline \multirow{4}{*}{ Brighton } & & & & & & $898,100,768$ & $\{34,524,179$ & & & 80.0470 & f29,666,630 & & 2.73 & 92.7 & \multirow{4}{*}{928} & & & & 43,680 & $\frac{172,010}{17010}$ & $44,477.29$ \\
\hline & & & & 1.141 & $10.000,000$ & 47335 & $£ 342,316$ & $f 211089.651$ & $f 679006,100$ & f0 0299 & $£ 36,195,380$ & $f 211089.651$ & & 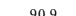 & & 8436 & & 21080 & 333 & 2.5775 & 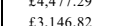 \\
\hline & \begin{tabular}{|l|} 
Enercon 4 \\
\end{tabular} & 72 & 926,020 & 139,335 & $\begin{array}{l}\mathrm{f} 180,000,000 \\
\mathrm{f}\end{array}$ & $\{126,864,740$ & $\varepsilon 41,800,470$ & $\mathrm{f} 348,665,210$ & $\begin{array}{l}6652,437,900 \\
6\end{array}$ & ${ }_{00.0351}$ & 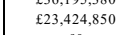 & 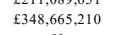 & $\begin{array}{l}2.35 \\
2.35\end{array}$ & $\begin{array}{l}95.4 \\
95.4\end{array}$ & & $\begin{array}{l}885.3 \\
83.3\end{array}$ & $\begin{array}{l}237,197 \\
237\end{array}$ & $\begin{array}{l}22,133 \\
22,133\end{array}$ & $\begin{array}{l}533 \\
56,487\end{array}$ & $\begin{array}{l}158,577 \\
15713\end{array}$ & 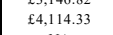 \\
\hline & 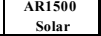 & $\begin{array}{l}0 \\
622,514\end{array}$ & $\begin{array}{l}0 \\
1,334,747\end{array}$ & $\begin{array}{c}0 \\
152,329 \\
\end{array}$ & $\begin{array}{c}\mathrm{f} 0 \\
\mathbb{f} 522,231,466\end{array}$ & $\begin{array}{c}\{0 \\
\{182,860,339\end{array}$ & 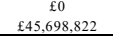 & 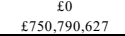 & 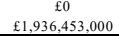 & $\begin{array}{c}\text { fo } \\
\{00.1571 \\
\mid\end{array}$ & $\begin{array}{c}£ 0 \\
£ 91,716,160\end{array}$ & $\begin{array}{c}\mathrm{f} 0 \\
\mathrm{E} 750,790,627 \\
\end{array}$ & $\begin{array}{c}0 \\
10.89 \\
\end{array}$ & $\begin{array}{c}0 \\
56.8 \\
\end{array}$ & & $\begin{array}{c}0 \\
527.1\end{array}$ & $\begin{array}{l}237,197 \\
237,197\end{array}$ & $\begin{array}{c}0 \\
30,572 \\
\end{array}$ & $\begin{array}{c}0 \\
81,420\end{array}$ & $\begin{array}{l}0 \\
125,205\end{array}$ & $\begin{array}{c}\mathrm{NA} \\
\mathbb{E 1 5 . 4 6 6 . 2 3} \\
.\end{array}$ \\
\hline \multirow{4}{*}{ Bristol } & \begin{tabular}{|l|l|} 
EWT 900 \\
\end{tabular} & 522 & 1,421,316 & \begin{tabular}{|l|l|}
225,159 \\
\end{tabular} & $\frac{252,2,000,000}{4522}$ & $\begin{array}{c}f 194,720,292 \\
\end{array}$ & 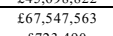 & $€ 784,267,855$ & $\frac{11,565,226,000}{f(1,600}$ & f0.0490 & $\notin 60,410,560$ & 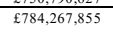 & 2.95 & 92.3 & \multirow{4}{*}{1769} & 1632.8 & 452,156 & 40,820 & 86,700 & 324,636 & E4,821.47 \\
\hline & & & & & 202,000,000 & , 449,734 & 3.,490 & $4,173,224$ & $22,947,000$ & & $\{71,612,690$ & $404,173,224$ & & 90.3 & & & & & 646 & & $43,231.35$ \\
\hline & $\mid \begin{array}{l}\text { Enercon } 4 \\
\text { AR1500 }\end{array}$ & $\begin{array}{l}{ }_{210}^{143} \\
210\end{array}$ & $\mid \begin{array}{l}1,365,0430 \\
37,078\end{array}$ & \begin{tabular}{|l|l|}
263,669 \\
13,510
\end{tabular} & 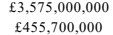 & 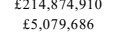 & 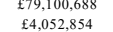 & $\begin{array}{l}£ 3,868,975,5988 \\
€ 446,832,540\end{array}$ & 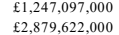 & 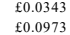 & 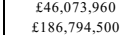 & 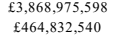 & $\begin{array}{l}2.31 \\
6.29\end{array}$ & $\begin{array}{l}95.1 \\
59.7 \\
\end{array}$ & & $\begin{array}{l}1682.3 \\
1056.1\end{array}$ & 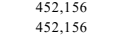 & 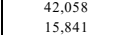 & $\begin{array}{l}95,674 \\
2,262\end{array}$ & $\begin{array}{l}\begin{array}{l}314,424 \\
434.053\end{array} \\
4\end{array}$ & $\begin{array}{l}£ 3,966.29 \\
6 \in, 632.26\end{array}$ \\
\hline & Solar & $1,092,251$ & $1,783,756$ & \begin{tabular}{|l|}
267,707 \\
\end{tabular} & $\{916,288,664$ & $£ 244,374,572$ & $£ 80,312,174$ & $\{1,240,975,410$ & $\begin{array}{r}84,036,222,000 \\
\end{array}$ & $\{0.1735$ & & $£ 1,240,975,410$ & & 43.2 & & 764.2 & 452,156 & 44,324 & 108,809 & 299,023 & $£$ \\
\hline \multirow{4}{*}{ Exeter } & \begin{tabular}{|l|l|} 
EWT 900 \\
\end{tabular} & 153 & \begin{tabular}{|l|l|}
437,440 \\
\end{tabular} & 66,847 & $\{153,000,000$ & $\begin{array}{l}{ }^{£ 5} 9,929,280 \\
\end{array}$ & $\{22,053,964$ & f232, & ${ }^{\varepsilon 462,52}$ & .0471 & & & 2.76 & $92.7 \mathrm{C}$ & \multirow{4}{*}{55.} & 16399.9 & 141,602 & 40,997 & 26,684 & 73,922 & $86,26.90$ \\
\hline & & ${ }^{62}$ & & & & & & 的3 & $\begin{array}{l}\text { E403, }, 794,200 \\
\end{array}$ & & & & & & & & & & & & 1.06 \\
\hline & \begin{tabular}{|l|} 
Enercon 4 \\
AR1500
\end{tabular} & $\begin{array}{l}43 \\
0\end{array}$ & $\begin{array}{c}513,315 \\
0\end{array}$ & $\begin{array}{c}85,120 \\
0\end{array}$ & 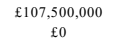 & $\underset{\substack{\mathrm{f} 70,324,155 \\
\mathrm{f}_{0}}}{2}$ & 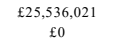 & $\underset{\substack{\mathrm{f} 203,360,176 \\
\mathrm{f} 0}}{0}$ & $\begin{array}{c}\mathfrak{\epsilon} 386,688,100 \\
\varepsilon_{0}\end{array}$ & $\begin{array}{c}f 0.0347 \\
\mathrm{f} 0\end{array}$ & $\{14,180,910$ & $\begin{array}{c}\mathrm{f} 203,360,176 \\
\kappa 0\end{array}$ & $\begin{array}{c}2.29 \\
0\end{array}$ & $\begin{array}{c}95.1 \\
0\end{array}$ & & $\begin{array}{c}526.9 \\
0.0\end{array}$ & 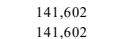 & $\begin{array}{c}13,171 \\
0\end{array}$ & $\begin{array}{c}31,312 \\
0\end{array}$ & $\begin{array}{c}97,119 \\
0\end{array}$ & $\begin{array}{l}\mathrm{E} 3.981 .56 \\
\mathrm{NA}\end{array}$ \\
\hline & & & 738,952 & 89,596 & $£ 306,696,470$ & $\{101,236,424$ & $\{26,878,843$ & $£ 434,811,737$ & $\varepsilon 1,201,134,000$ & $\{0.1639$ & $\begin{array}{r}£ 59,278,350 \\
\end{array}$ & $\begin{array}{r}£ 444,811,737 \\
\end{array}$ & 11.80 & 52.2 & & 289.2 & $\begin{array}{l}141,602 \\
1402\end{array}$ & 16,773 & 45,076 & 79,753 & $15,060.59$ \\
\hline \multirow{3}{*}{ Leiester } & \begin{tabular}{|l|} 
EWT 900 \\
\end{tabular} & 392 & \begin{tabular}{|l|l|l|}
$1,066,051$ \\
\end{tabular} & \begin{tabular}{|l|l|}
164,636 \\
\end{tabular} & 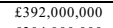 & & $\begin{array}{l}449,390,849 \\
\end{array}$ & & 000 & f0.0494 & & & 3 & 92.2 & \multirow{3}{*}{1310} & & & 30,196 & 65,029 & 611 & 898.95 \\
\hline & \begin{tabular}{|l|} 
GE 2.5 \\
Enercon 4
\end{tabular} & $\begin{array}{l}152 \\
106\end{array}$ & \begin{tabular}{|l|l|}
$\begin{array}{r}7,550 \\
1,090,446\end{array}$ \\
\end{tabular} & $\begin{array}{l}1,774 \\
192,106\end{array}$ & 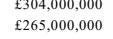 & 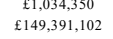 & 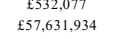 & 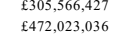 & 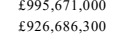 & 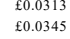 & 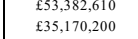 & 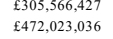 & 2.27 & $\begin{array}{l}90.4 \\
94.7\end{array}$ & & $\begin{array}{l}1184.2 \\
1240.6\end{array}$ & $\begin{array}{l}334,436 \\
334,836\end{array}$ & $\begin{array}{l}\begin{array}{l}29,606 \\
31,014\end{array} \\
3\end{array}$ & $\begin{array}{l}461 \\
66,517\end{array}$ & $\begin{array}{l}304,769 \\
237,305\end{array}$ & 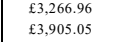 \\
\hline & \begin{tabular}{|l|} 
AR1500 \\
Solar
\end{tabular} & $\begin{array}{l}0 \\
825677\end{array}$ & $\begin{array}{c}0 \\
1.445766\end{array}$ & 0 & $\begin{array}{c}\mathfrak{f 0} \\
\mathbb{f 6 9 2 . 6 6 2 . 6 5 3}\end{array}$ & $\begin{array}{c}f 0 \\
f 1980.9692 \\
f\end{array}$ & $\begin{array}{c}€ 0 \\
f 613092925 \\
f\end{array}$ & $\begin{array}{c}f 0 \\
f 952042520\end{array}$ & 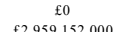 & 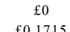 & $\begin{array}{c}£ 0 \\
f 1525870\end{array}$ & $\begin{array}{l}\varepsilon 0 \\
052520\end{array}$ & ${ }^{0}$ & 0 & & 00 & $\begin{array}{l}334,836 \\
334836\end{array}$ & 00 & 80 & ${ }^{0}$ & *DIV/0! \\
\hline \multirow{4}{*}{ Manchester } & \begin{tabular}{|c|} 
Solar \\
EWT 900 \\
\end{tabular} & $\frac{825,697}{759}$ & $\frac{1,144,566}{2,086,262}$ & \begin{tabular}{|l|}
204,466 \\
34,095 \\
\end{tabular} & $\begin{array}{l}\frac{6692,662,633}{6759,000,000} \\
\end{array}$ & 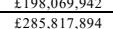 & $\frac{\varepsilon=1,309 .}{694,228 .}$ & $\frac{\varepsilon y 92,244}{f 1,139,0}$ & $\frac{959,15}{287,27}$ & 1.0498 & & & & & \multirow{4}{*}{2544} & & & 58, & & & $\begin{array}{l}13,944.44 \\
44.925 .13\end{array}$ \\
\hline & 5 & 295 & $\mid$ & 3.444 & 00 & 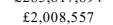 & $\neq 1$ & 841 & 000 & $\{0.0315$ & 200 & 41 & 1.61 & $\begin{array}{l}22.1 \\
90.3\end{array}$ & & $\begin{array}{l}2343.0 \\
2297.2\end{array}$ & $\begin{array}{l}\begin{array}{l}630,0,46 \\
650,246\end{array} \\
6\end{array}$ & $\begin{array}{l}38, \\
57,\end{array}$ & $\begin{array}{l}12,762 \\
894\end{array}$ & 21 & .81 \\
\hline & \begin{tabular}{|l|} 
Enercon 4 \\
\end{tabular} & 206 & 2,233,360 & \begin{tabular}{|l|}
370,509 \\
\end{tabular} & $\notin 515,000,000$ & $f 305,970,320$ & $\{111,152,689$ & $£ 932,123,009$ & $\begin{array}{ll}f 1,805,709,000 \\
\end{array}$ & ${ }_{f 0.0347}$ & $\varepsilon 67,575,700$ & ${ }_{6932}$ & 2.31 & 94.9 & & 2414.3 & & 60,356 & 136,235 & 453,655 & €3,980.36 \\
\hline & \begin{tabular}{|l|} 
AR1500 \\
solar
\end{tabular} & $\begin{array}{l}0 \\
1.599 .411 \\
\end{array}$ & $\begin{array}{l}0 \\
2846005\end{array}$ & \begin{tabular}{|c|}
0 \\
396929 \\
\end{tabular} & $\begin{array}{c}\{0 \\
f 1341.79 .144 \\
f\end{array}$ & 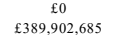 & $\begin{array}{c}\epsilon_{0} \\
\varepsilon 119.078 .765\end{array}$ & $\begin{array}{l}60 \\
61.50 .7 \\
0\end{array}$ & 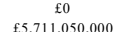 & 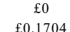 & $\begin{array}{c}£ 0 \\
\{298,613,400\end{array}$ & $\begin{array}{c}€ 0 \\
f 1850.20 .594\end{array}$ & $\begin{array}{c}0 \\
1270\end{array}$ & ${ }_{461}^{0}$ & & 0 & $\begin{array}{l}650,246 \\
6550246\end{array}$ & $\begin{array}{c}0 \\
68.021\end{array}$ & $\begin{array}{c}0 \\
173.606 \\
173\end{array}$ & $\stackrel{0}{0}$ & $\begin{array}{c}\mathrm{NA} \\
\mathrm{NA}\end{array}$ \\
\hline & \begin{tabular}{|l|l|} 
EWT 900 \\
\end{tabular} & 326 & \begin{tabular}{|l|l|l|l}
926,847 \\
\end{tabular} & 143,140 & & & & & & & & & 2.75 & $\frac{7.1}{92.4}$ & & 1096.8 & & 27 & 56,538 & 219,440 & \\
\hline & & & & & & & & & & & & & & & & & & & & & \\
\hline Newcastle & Enercon 4 & 92 & $1,086,521$ & 185,224 & $£ 230,000,000$ & $\{148,853,377$ & $\{55,567,347$ & $£ 434,420,724$ & $\notin 831,778,000$ & f0.0350 & $\{30,737,322$ & ${ }^{4} 434,420,724$ & 2.29 & 95 & 1187 & 1127 & 303,397 & 28,191 & 66,278 & 208,928 & $£ 3,981.17$ \\
\hline & & 0 & $\begin{array}{l}0 \\
08777 \\
887\end{array}$ & 0 & fo & 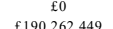 & & & & & & & & & & & & & & & \\
\hline & EWT 900 & $\frac{10,13}{233}$ & 6880,564 & \begin{tabular}{|l|l|}
108,9076 \\
\end{tabular} & & & ${ }^{632}$ & & & & & & 2.64 & 1.4 & & 8. & & & & & $\{4,300.29$ \\
\hline Plymouth & $\begin{array}{l}\text { GE } 2.5 \\
\end{array}$ & 95 & 5,108 & 1,129 & $\begin{array}{l}£ 190,000,000 \\
\end{array}$ & $\begin{array}{l}6699,796 \\
\end{array}$ & 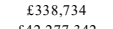 & $£ 191,038,530$ & $\begin{array}{l}863,622,400 \\
663,2300\end{array}$ & 0300 & & $£ 1$ & 1.7 & . & 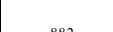 & 年 & & 19,999 & 102 & 205,128 & $£ 3,088.91$ \\
\hline Plymouth & \begin{tabular}{|l|} 
Enerconon \\
\end{tabular} & 64 & 865,268 & 140,924 & $\begin{array}{l}1160,000,000 \\
\text { f0 }\end{array}$ & 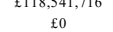 & $\begin{array}{c}\qquad 42,2,27,342 \\
\leqslant 0\end{array}$ & $\$ 320,819,058$ & 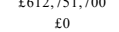 & 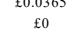 & $\begin{array}{l}\mathrm{f} 22,582,260 \\
£ 0\end{array}$ & 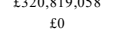 & 2.27 & 94.9 & 882 & 837.0 & $\begin{array}{l}222,3439 \\
225,439\end{array}$ & $\begin{array}{l}20,925 \\
0\end{array}$ & $\begin{array}{c}52,781 \\
0\end{array}$ & $\begin{array}{l}151,732 \\
0\end{array}$ & $\begin{array}{l}£ 4,038.37 \\
\text { NA }\end{array}$ \\
\hline & & 446 & $\frac{135}{4}$ & 42,218 & $£ 486,940,883$ & & & f6960.06 & $1,876,3:$ & 66 & & & 11.27 & 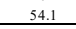 & & $477 \mathrm{C}$ & & & & & \\
\hline & & 239 & & & & & & & & & & & & & & & & & & & \\
\hline Portsmouth & & 94 & & & & & & & & & & & $\begin{array}{ll}1.53 \\
2.2\end{array}$ & $\begin{array}{l}90.9 \\
0.52\end{array}$ & 880 & & & & & & \\
\hline & & & & & & & & & & & & & & & & & & & & & \\
\hline & in & 585,239 & 1,26 & 144,0 & $\begin{array}{r}\varepsilon 490,961,683 \\
0,5000\end{array}$ & $£ 172,978,529$ & 88 & & 000 & $£ 0.1572$ & 780 & $1,159,000$ & 10.85 & 56.5 & & 497 & & & & 71 & \\
\hline & .5 & $\begin{array}{l}245 \\
101\end{array}$ & 20 & $\begin{array}{c}101 \\
1.2\end{array}$ & 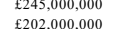 & $\begin{aligned} £ 89,2 \\
\mathfrak{f} 727\end{aligned}$ & 94 & 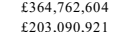 & 5.522800 & 64 & $\begin{array}{l}\{30,377,220 \\
\epsilon 34,97590\end{array}$ & 2 & 158 & $\begin{array}{l}91.6 \\
907\end{array}$ & & 80 & & 20 & & & 77 \\
\hline Swanse: & & 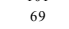 & 83 & 132 & . & $\{113$, & $, 724,860$ & $26,217,080$ & $3,006,600$ & 33 & 90 & 80 & 2.3 & 95 & 888 & 84 & 22 & 21 & 50 & 27 & 1.90 \\
\hline & Solar & 537944 & 890.396 & 135244 & $f_{4551} 128,677$ & $f(121.984 .252$ & $f_{40.567 .204}$ & 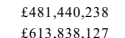 & 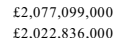 & $f_{0} 0.1733$ & 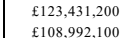 & $f 613838,127$ & 1311 & $\begin{array}{l}34.0 \\
428\end{array}$ & & 3801 & 226.673 & . & 54.314 & 150.615 & f13,430. \\
\hline
\end{tabular}




\section{References}

1. UK Government. UK Sets Ambitious New Climate Change Target Ahead of UN Summit. 2020. Available online: https: //www.gov.uk/government/news/uk-sets-ambitious-new-climate-target-ahead-of-un-summit (accessed on 14 October 2020).

2. Shahzad, A.; Ullah, S.; Dar, A.A.; Sardar, M.F.; Mehmood, T.; Tufail, M.A.; Shakoor, A.; Haris, M. Nexus on climate change: Agriculture and possible solution to cope future climate change stresses. Environ. Sci. Pollut. Res. 2021, 28, 14211-14232. [CrossRef] [PubMed]

3. Wainwright, C.M.; Finney, D.L.; Kilavi, M.; Black, E.; Marsham, J.H. Extreme rainfall in East Africa, October 2019-January 2020 and context under future climate change. Weather 2021, 76, 26-31. [CrossRef]

4. United States Environmental Protection Agency (USEPA). Climate Change Indicators: Weather and Climate. 2020. Available online: https: / / www.epa.gov / climate-indicators / weather-climate (accessed on 16 October 2020).

5. Sebo, J. Animals and Climate Change. In Philosophy Climate Change; Oxford University Press: Oxford, UK, $2021 ;$ p. 42.

6. Wang, Z.; Tsementzi, D.; Williams, T.C.; Juarez, D.L.; Blinebry, S.K.; Garcia, N.S.; Sienkiewicz, B.K.; Konstantinidis, K.T.; Johnson, Z.I.; Hunt, D.E. Environmental stability impacts the differential sensitivity of marine microbiomes to increases in temperature and acidity. ISME J. 2021, 15, 19-28. [CrossRef] [PubMed]

7. Wang, M.; Zhou, T.; Song, Y.; Li, X.; Ma, H.; Hu, Y.; Heianza, Y.; Qi, L. Joint exposure to various ambient air pollutants and incident heart failure: A prospective analysis in UK Biobank. Eur. Heart J. 2021, 42, 1582-1591. [CrossRef] [PubMed]

8. Kampa, M.; Castanas, E. Human health effects of air pollution. Environ. Pollut. 2008, 151, 362-367. [CrossRef] [PubMed]

9. London Councils. Air Pollution and the Effect on Our Health. 2020. Available online: https://www.londoncouncils.gov.uk/ node/33227 (accessed on 3 November 2020).

10. Diouf, B.; Pode, R. Potential of lithium-ion batteries in renewable energy. Renew. Energy 2015, 76, 375-380. [CrossRef]

11. British Petroleum (BP). Statistical Review of World Energy. 2020. Available online: https://www.bp.com/content/dam/bp/ business-sites/en/global/corporate/pdfs/energy-economics/statistical-review/bp-stats-review-2020-full-report.pdf (accessed on 7 December 2020).

12. Institute for Energy Economics and Financial Analysis (IEEFA). Record Setting 2.2GW Solar Park in India Now Fully Operational. 2020. Available online: https://ieefa.org/record-setting-2-2gw-solar-park-in-india-now-fully-operational/ (accessed on 7 December 2020).

13. NASA. Earth Observatory. Longyangxia Dam Solar Park. 2017. Available online: https://earthobservatory.nasa.gov/images/89 668/longyangxia-dam-solar-park (accessed on 8 December 2020).

14. Akrami, M.; Gilbert, S.J.; Dibaj, M.; Javadi, A.A.; Farmani, R.; Salah, A.H.; Fath, H.E.S.; Negm, A. Decarbonisation Using Hybrid Energy Solution: Case Study of Zagazig, Egypt. Energies 2020, 13, 4680. [CrossRef]

15. Nasab, N.M.; Kilby, J.; Bakhtiaryfard, L. Case Study of a Hybrid Wind and Tidal Turbines System with a Microgrid for Power Supply to a Remote Off-Grid Community in New Zealand. Energies 2021, 14, 3636. [CrossRef]

16. Mekonnen, T.; Bhandari, R.; Ramayya, V. Modeling, Analysis and Optimization of Grid-Integrated and Islanded Solar PV Systems for the Ethiopian Residential Sector: Considering an Emerging Utility Tariff Plan for 2021 and beyond. Energies 2021, 14, 3360. [CrossRef]

17. Alqahtani, N.; Balta-Ozkan, N. Assessment of Rooftop Solar Power Generation to Meet Residential Loads in the City of Neom, Saudi Arabia. Energies 2021, 14, 3805. [CrossRef]

18. Ye, B.; Zhou, M.; Yan, D.; Li, Y. Multi-Objective Decision-Making for Hybrid Renewable Energy Systems for Cities: A Case Study of Xiongan New District in China. Energies 2020, 13, 6223. [CrossRef]

19. Upadhyay, S.; Sharma, M. A review on configurations, control and sizing methodologies of hybrid energy systems. Renew. Sustain. Energy Rev. 2014, 38, 47-63. [CrossRef]

20. Millward-Hopkins, J.; Tomlin, A.; Ma, L.; Ingham, D.; Pourkashanian, M. Mapping the wind resource over UK cities. Renew. Energy 2013, 55, 202-211. [CrossRef]

21. United Nations. United Nations Climate Change. The Paris Agreement. 2015. Available online: https://unfccc.int/process-andmeetings/the-paris-agreement/the-paris-agreement (accessed on 13 October 2020).

22. International Panel for Climate Control (IPCC). Summary for Policymakers. 2018. Available online: https://www.ipcc.ch/site/ assets/uploads/sites/2/2019/05/SR15_SPM_version_report_LR.pdf (accessed on 14 October 2020).

23. Logadottir, H. Iceland's Sustainable Energy Story. United Nations. Available online: https://www.un.org/en/chronicle/article/ icelands-sustainable-energy-story-model-world (accessed on 22 November 2020).

24. Scottish Government. Energy Statistics for Scotland Q4 2020. 2021. Available online: https://www.gov.scot/binaries/content/ documents/govscot/publications/statistics/2018/10/quarterly-energy-statistics-bulletins/documents/energy-statisticssummary---march-2021/energy-statistics-summary---march-2021/govscot:document/Scotland+Energy+Statistics+Q4+2020 pdf (accessed on 25 November 2020).

25. Simoes, S.; Dias, L.; Gouveia, J.P.; Seixas, J.; De Miglio, R.; Chiodi, A.; Gargiulo, M.; Long, G.; Giannakidis, G. InSmart-A methodology for combining modelling with stakeholder input towards EU cities decarbonisation. J. Clean. Prod. 2019, 231, 428-445. [CrossRef]

26. Hsu, A.; Höhne, N.; Kuramochi, T.; Vilariño, V.; Sovacool, B.K. Beyond states: Harnessing sub-national actors for the deep decarbonisation of cities, regions, and businesses. Energy Res. Soc. Sci. 2020, 70, 101738. [CrossRef] 
27. Ryan, C.; Twomey, P.; Gaziulusoy, I.; McGrail, S.; Candy, S.; Larsen, K.; Trudgeon, M.; Chandler, P. Visions, Scenarios and Pathways for Rapid Decarbonisation of Australian Cities by 2040. Decarbonising Built Environ. 2019, 507-528.

28. Lago, L.; Ponta, F.; Chen, L. Advances and trends in hydrokinetic turbine systems. Energy Sustain. Dev. 2010, 14, 287-296. [CrossRef]

29. Hussain, A.; Arif, S.M.; Aslam, M. Emerging renewable and sustainable energy technologies: State of the art. Renew. Sustain. Energy Rev. 2017, 71, 12-28. [CrossRef]

30. Tesla. Megapack. 2021. Available online: https://www.tesla.com/en_gb/megapack (accessed on 15 January 2021).

31. Gravitricity. Fast, Long Life Energy Storage. Available online: https://gravitricity.com/technology/ (accessed on 19 October 2020).

32. Energy Vault. Commercial Demonstration Unit. 2021. Available online: https://energyvault.com/commercial-demonstrationunit/ (accessed on 19 October 2020).

33. Blunden, L.S.; Bahaj, A.S. Tidal energy resource assessment for tidal stream generators. Proc. Inst. Mech. Eng. Part A J. Power Energy 2007, 221, 137-146. [CrossRef]

34. Cavazzi, S.; Dutton, A.G. An Offshore Wind Energy Geographic Information System (OWE-GIS) for assessment of the UK's offshore wind energy potential. Renew. Energy 2016, 87, 212-228. [CrossRef]

35. HOMER Energy. HOMER Pro Software. 2021. Available online: https://www.homerenergy.com/products/pro/index.html (accessed on 23 October 2020).

36. UK Government. Regional and Local Authority Electricity Consumption Statistics. 2020. Available online: https://www.gov. $\mathrm{uk}$ /government/statistical-data-sets/regional-and-local-authority-electricity-consumption-statistics (accessed on 29 September 2020).

37. World Bank Group. Global Solar Atlas. 2021. Available online: https://globalsolaratlas.info/map (accessed on 8 October 2020).

38. World Bank Group. Global Wind Atlas. 2021. Available online: https://globalwindatlas.info/ (accessed on 8 October 2020).

39. Myres, J. Admiralty Tidal Stream Atlas NP250, 4th ed.; UK Hydrographic Office: Taunton, UK, 1992.

40. NASA. The Power Project. 2019. Available online: https://power.larc.nasa.gov/ (accessed on 4 December 2020).

41. Ofgem. Bills, Prices and Profits. 2021. Available online: https://www.ofgem.gov.uk/publications-and-updates/infographicbills-prices-and-profits (accessed on 13 February 2021).

42. Bloomberg. USD:GBP. 2021. Available online: https://www.bloomberg.com/quote/USDGBP:CUR (accessed on 3 March 2021).

43. Bloomberg. EUR:GBP. 2021. Available online: https://www.bloomberg.com/quote/EURGBP:CUR (accessed on 3 March 2021).

44. Orbital Marine. Creating Clean Power from Flowing Water. 2021. Available online: https://orbitalmarine.com/technology/ (accessed on 3 December 2020).

45. Equinor. The Future of Offshore Wind is Afloat. 2021. Available online: https://www.equinor.com/en/what-we-do/floatingwind.html (accessed on 5 April 2021).

46. Renewables First. Location and Size of Wind Turbines. Available online: https://www.renewablesfirst.co.uk/windpower/ community-windpower/location-size-no-of-wind-turbines/ (accessed on 6 April 2021).

47. Sciencing. How Much Land is Needed for Wind Turbines? 2018. Available online: https://sciencing.com/much-land-neededwind-turbines-12304634.html (accessed on 6 April 2021).

48. Enercon. Enercon E-126 EP3. 2016. Available online: https://www.enercon.de/en/products/ep-3/e-126-ep3/ (accessed on 13 January 2021).

49. DNV. Tidal Turbines. 2015. Available online: https://rules.dnv.com/docs/pdf/DNV/ST/2015-10/DNVGL-ST-0164.pdf (accessed on 3 April 2021).

50. Simec Atlantis. AR1500 Tidal Turbine. Simec Atlantis. Available online: https://simecatlantis.com/wp-content/uploads/2016/0 8/AR1500-Brochure-Final-1.pdf (accessed on 7 February 2021).

51. Impulsora. Megapack. Tesla. 2020. Available online: https://impulsora.com/wp-content/uploads/2020/09/Ficha-TecnicaMega-Pack.pdf (accessed on 3 April 2021). 